University of Michigan Law School

University of Michigan Law School Scholarship Repository

Law \& Economics Working Papers

$10-29-2015$

\title{
With Marriage on the Decline and Cohabitation on the Rise, What about Marital Rights for Unmarried Partners?
}

\author{
Lawrence W. Waggoner \\ University of Michigan Law School, waggoner@umich.edu
}

Follow this and additional works at: https://repository.law.umich.edu/law_econ_current

Part of the Family Law Commons, Law and Economics Commons, Taxation-Federal Commons, and the Tax Law Commons

\section{Working Paper Citation}

Waggoner, Lawrence W., "With Marriage on the Decline and Cohabitation on the Rise, What about Marital Rights for Unmarried Partners?" (2015). Law \& Economics Working Papers. 123.

https://repository.law.umich.edu/law_econ_current/123

This Article is brought to you for free and open access by University of Michigan Law School Scholarship Repository. It has been accepted for inclusion in Law \& Economics Working Papers by an authorized administrator of University of Michigan Law School Scholarship Repository. For more information, please contact mlaw.repository@umich.edu. 


\section{With MarRiage ON THE DeCline AND CoHABITATION ON THE Rise, What ABOUT MARITAL RIGHTS FOR UNMARRIED PARTNERS?}

41 ACTEC L.J. (pts. 1 \& 2) (forthcoming Jan. \& Feb. 2016) Lawrence W. Waggoner ${ }^{* *}$

Part I of this paper uses recent government data to trace the decline of marriage and the rise of cohabitation in the United States. Between 2000 and 2010, the population grew by $9.71 \%$, but the husband and wife households only grew by $3.7 \%$, while the unmarried couple households grew by $41.4 \%$. A counter-intuitive finding is that the early 21 st century data show little correlation between the marriage rate and economic conditions.

Because of the Supreme Court's decision in Obergefell v. Hodges (2015), same-sex marriage is now universally available to same-sex couples. Part I considers the impact of same-sex marriage on the marriage rate. Part I then describes the benefits and obligations of marriage and closes by noting the demographic characteristics of cohabiting couples. The paper points out that cohabitation is a temporary or short-term state in most cases: The parties either break up or get married fairly quickly. Nevertheless, a small percentage of cohabiting couples continue to cohabit for much longer or for life. Because more are added every year, these cohabitations accumulate in the population.

Part II discusses how the case law has addressed the rights and obligations of cohabiting couples when they break up. Titled From Contract to Status, this Part starts with the enforcement of contracts between the parties, then moves to the right of plaintiffs when they do not allege or cannot prove a contract. One route to recovery would be common-law marriage, but that concept was abolished by late-19th century

* A shorter version of this article will appear in a symposium on cohabitation published in the Summer 2016 issue of the Family Law Quarterly.

${ }^{* *}$ Lewis M. Simes Professor Emeritus of Law, University of Michigan. For commenting on earlier drafts, I thank David Chambers, Bruce Frier, and John Langbein. 
Prepublication Draft: Marital Rights for Unmarried Partners?

statutes in almost every American jurisdiction. Nevertheless, in states that have abolished common-law marriage, cases exist in which the court awarded damages to the plaintiff based on status, i.e., in which the court described the couple's relationship as a marriage in all but name.

Part III argues the case for treating cohabiting couples whose relationship shows that they are (or were) deeply committed to one another as married in fact. The paper finds that a consensus of sorts has quietly emerged in legislation to this effect that has been enacted or introduced in the United Kingdom, Australia, Canada, and New Zealand. In this country, the American Law Institute (ALI) has recognized that longer-term cohabitants have rights similar to married couples upon dissolution of the relationship. Drawing on the $U K$ and Commonwealth statutes, the ALI proposal, and the case law described in Part II, the paper presents for discussion a draft De Facto Marriage Act. The Draft Act, however, along with the Commonwealth statutes and the ALI proposal, does not, and probably should not, provide a mechanism for automatically declaring a couple as married in fact. Couples who deliberately decline to marry should not have their decision overridden. Consequently, the Draft Act is not set up to be self-executing. A court judgment is required.

The paper concludes by pointing out that a de facto marriage judgment would qualify a couple for all federal as well as state benefits and obligations of marriage.

I. Introduction: Marriage and Cohabitation Rates. . . . . . . . 3

A. The Decline of Marriage. . . . . . . . . . . . . 3

B. The Rise of Cohabitation................ 6

C. Impact of Same-Sex Marriage on the Marriage Rate. . . . 11

D. The Benefits, Rights, and Obligation of Marriage. . . . . 13

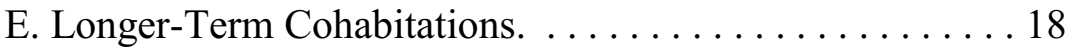

II. Case Law: From Contract to Status. . . . . . . . . . . . . 21

A. Recovery Based on Contract. . . . . . . . . . . . 21

B. Recovery Based on Status. . . . . . . . . . . 30 
Prepublication Draft: Marital Rights for Unmarried Partners?

1. Common-Law Marriage................... 30

2. In States that Have Abolished Common-Law

Marriage.................... 34

III. A Uniform De Facto Marriage Act?. . . . . . . . . . . . 41

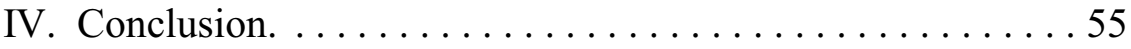

I. INTRODUCTION:

\section{MARRIAGE AND COHABITATION RATES}

\section{A. The Decline of Marriage}

Between 1867 and 1967, the annual marriage rate changed little: $0.96 \%$ of the population married in 1867 and $0.97 \%$ in 1967 . In the intervening years, the rated dipped as low as $0.79 \%$ during the Great Depression in 1932 and spiked up to $1.46 \%$ when the troops came home after the end of World War II. The annual percentage during ninety of these years ranged between $0.85 \%$ and $1.14 \%{ }^{1}$

By 2000 , the marriage rate had declined to $0.82 \%$. The rate continued to spiral downward, reaching an historic low of slightly less than $0.68 \%$ in 2009. From 2009 to 2012, the latest years for which marriage-rate statistics are available, the marriage rate stabilized at that historically low rate of slightly less than $0.68 \%:^{2}$

1 See Public Health Service, U.S. DeP't of Health, Education, and WELFARE, 100 Years of Marriage and Divorce Statistics United States, 1867-1967, at 7 (DHEW Pub. No. (HRA) 74-1902, Dec. 1973), available at http://www.cdc.gov/nchs/data/series/sr_21/sr21_024.pdf.

${ }^{2}$ Demographic Intelligence, a consulting firm that claims that its demographic forecasts are 99\% accurate, predicts: "The United State marriage rate is . . . is poised to go lower . . .." DEMOGRAPHIC InTELligENCE, United States Marriage Rate, at Century Low, Headed Down, at 1 (May 15, 2015), available at http://www.demographicintel.com/wp-content/uploads/2015/06/US_Wedding_P R_5.15.15.pdf. 
Prepublication Draft: Marital Rights for Unmarried Partners?

Table 1

Number of Marriages, Marriage and Unemployment Rates. Gross

Domestic Product: 2000-2012

\begin{tabular}{|c|c|c|c|c|c|}
\hline Year & $\begin{array}{c}\text { Number of } \\
\text { Marriages }\end{array}$ & Population & $\begin{array}{c}\text { Percentage } \\
\text { of the } \\
\text { Population } \\
\text { Getting } \\
\text { Married }\end{array}$ & $\begin{array}{c}\text { Unemploy- } \\
\text { ment Rate } \\
\text { of Those } \\
\text { Seeking } \\
\text { Employ- } \\
\text { ment }\end{array}$ & $\begin{array}{c}\text { Gross } \\
\text { Domestic } \\
\text { Product in } \\
\text { Billions of } \\
\text { Chained } \\
\text { 2009 } \\
\text { Dollars }\end{array}$ \\
\hline 2000 & $2,315,000$ & $281,421,906$ & 0.82261 & $4.0 \%$ & $\$ 12,559.7$ \\
\hline 2001 & $2,326,000$ & $284,968,955$ & 0.81623 & $4.7 \%$ & $\$ 12,682.2$ \\
\hline 2002 & $2,290,000$ & $287,625,193$ & 0.79618 & $5.8 \%$ & $\$ 12,908.8$ \\
\hline 2003 & $2,245,000$ & $290,107,933$ & 0.77385 & $6.0 \%$ & $\$ 13,271.1$ \\
\hline 2004 & $2,279,000$ & $292,805,298$ & 0.77833 & $5.5 \%$ & $\$ 13,773.5$ \\
\hline 2005 & $2,249,000$ & $295,516,599$ & 0.76104 & $5.1 \%$ & $\$ 14,234.2$ \\
\hline 2006 & $2,193,000$ & $294,077,247$ & 0.74572 & $4.6 \%$ & $\$ 14,613.8$ \\
\hline 2007 & $2,197,000$ & $301,231,207$ & 0.72934 & $4.6 \%$ & $\$ 14,873.7$ \\
\hline 2008 & $2,157,000$ & $304,093,966$ & 0.70932 & $5.8 \%$ & $\$ 14,830.4$ \\
\hline 2009 & $2,080,000$ & $306,771,529$ & 0.67803 & $9.3 \%$ & $\$ 14,418.7$ \\
\hline 2010 & $2,096,000$ & $308,745,538$ & 0.67888 & $9.6 \%$ & $\$ 14,738.8$ \\
\hline 2011 & $2,118,000$ & $311,591,917$ & 0.67974 & $8.9 \%$ & $\$ 15,020.6$ \\
\hline 2012 & $2,131,000$ & $313,914,040$ & 0.67885 & $8.1 \%$ & $\$ 15,354.6$ \\
\hline
\end{tabular}

${ }^{3}$ The first four columns are based on the 2000-2012 marriage-rate table in NAT'L Center For Health Statistics, CenTER For Disease Control, National Marriage and Divorce Rate Trends, at 1 (Feb. 19, 2015), available at http://www.cdc.gov/nchs/nvss/marriage divorce tables.htm. See also Isabel V. Sawhill, Beyond Marriage, N.Y. TIMES, Sept. 13, 2014, available at http://www.nytimes.com/2014/09/14/opinion/sunday/beyond-marriage.html?_r=1 ("Marriage is disappearing.").

${ }^{4}$ See Bureau of Labor Statistics, Labor Force Statistics, available at http://data.bls.gov/timeseries/LNU04000000?years_option=all_years\&periods_o ption=specific_periods\&periods $=$ Annual + Data.

${ }^{5}$ See Bureau of ECONOMIC ReSEARCH, National Economic Accounts, Gross Domestic Product (GDP), available at http://bea.gov/national/index.htm\#gdp. 


\section{Prepublication Draft: Marital Rights for Unmarried Partners?}

Although the marriage rate dipped substantially during the Great Depression of the 1930s, a counter-intuitive finding is that the early $21^{\text {st }}$ century data in Table 1 show little correlation between the marriage rate and economic conditions. The marriage rate was declining long before the 2008-09 recession and declined at only a slightly accelerated pace during the second year of that recession. Just as the 2009-2012 marriage rate stabilized, the unemployment rate spiked up from below $6.0 \%$ to over $9.0 \%$ despite improvement in the gross domestic product. These data points do not mean that a dramatically improved economy sometime in the future might not correlate with a rising marriage rate, but that cannot now be known. So far though, current data show that the 2015 unemployment rate for those in the likely first-marriage ages - the millennials (18- to 34year-olds) - is down to $7.7 \%$, but that has not led them to form more households than they did before the recession began. ${ }^{6}$

Analyzing U.S. Census data, the Pew Research Center found that "[i]n 1960, 72\% of all adults age 18 and older were married; [in 2010 ,] just $51 \%$ are." "The Center also found that "just $20 \%$ of adults ages 18 to 29 are married, compared with 59\% in 1960, [though it] is not yet known whether today's young adults are abandoning marriage or merely delaying it." The Center also found that "[p]ublic opinion about marriage echoes the declining prevalence of marriage. In a 2010 Pew Research Center survey, about four-in-ten Americans $(39 \%)$ said they agree that marriage as an institution is becoming

${ }^{6}$ See Richard Fry, Pew Research Center, More Millennial Living With Family Despite Improved Job Market, at 2 (July 29, 2015), available at http://www.pewsocialtrends.org/2015/07/29/more-millennials-living-with-family -despite-improved-job-market/.

${ }^{7}$ D'Vera Cohn et al., Pew Research CENTER, Barely Half of U.S. Adults Are Married-A Record Low, at 1 (Dec. 14, 2011), available at http://www.pewsocialtrends.org/2011/12/14/barely-half-of-u-s-adults-are-marrie d-a-record-low/ [hereinafter Pew: Less than Half Are Married]. See also PEW RESEARCH CENTER, The Decline of Marriage and Rise of New Families, at 1 (Paul Taylor ed. Nov. 18, 2010$), \quad$ available at http://www.pewresearch.org/pubs/1802/decline-marriage-rise-new-families("About half [52\%] of all adults in this country were married in 2008; back in 1960, sevenin-ten [72\%] were.") [hereinafter Pew: The Decline of Marriage \& Rise of New Families].

${ }^{8}$ Pew: Less than Half Are Married, supra note 7, at 2. 


\section{Prepublication Draft: Marital Rights for Unmarried Partners?}

obsolete. Back in the 70 s, only $28 \%$ agreed with that premise.... However, attitudes toward the institution of marriage do not always match personal wishes about getting married. Asked whether they want to get married, $47 \%$ of unmarried adults who agree that marriage is becoming obsolete say that they would like to wed.",

\section{B. The Rise of Cohabitation}

As the marriage rate has declined, the cohabitation rate has risen. ${ }^{10}$ According to the latest Census Bureau report, "the unmarried partner population numbered 7.7 million in 2010 and grew 41\% between 2000 and 2010."11

${ }^{9} \mathrm{Id}$. at 6 .

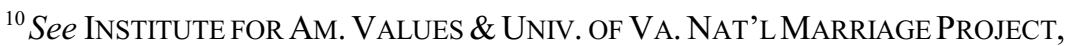
THE STATE OF OUR UNIONS: MARRIAGE IN AMERICA 2012 (Dec. 2012) [hereinafter MARRIAGE IN AMERICA], at 64 ("The decline in marriage does not mean that people are giving up on living together with a sexual partner. On the contrary, with the incidence of unmarried cohabitation increasing rapidly, marriage is giving ground to unwed unions."), 76 ("For many, cohabitation is a prelude to marriage, for others simply an alternative to living alone, and for a small but growing number it is considered an alternative to marriage."), available at http://stateofourunions.org/2012/SOOU2012.pdf; U.S. CENSUS BUREAU, MarriedCouple and Unmarried Partner Households: 2000, at 1 (Feb. 2003), available at http://www.census.gov/prod/2003pubs/censr-5.pdf; Pew: The Decline of Marriage \& Rise of New Families, supra note 4, at 66-67; DEMOGRAPHIC INTELLIGENCE, supra note 2, at 2 ("Cohabitation has emerged as a competitor to marriage, insofar as it offers intimacy and the opportunity to have children without requiring the same level of commitment."). See also Pew: Less than Half Are Married, supra note 4, at 1 ;

${ }^{11}$ See U.S. Census Bureau, Households and Families: 2010, at 3 (April 2012), available at http://www.census.gov/prod/cen2010/briefs/c2010br-14.pdf.

$-6-$ 
Prepublication Draft: Marital Rights for Unmarried Partners?

Table 2

Households by Type: 2000 and $2010^{12}$

\begin{tabular}{|c|c|c|c|c|c|c|}
\hline Household Type & \multicolumn{2}{|c|}{$\begin{array}{l}2000 \\
\text { ber } \\
\text { Percent of } \\
\text { ll Households }{ }^{13}\end{array}$} & \multicolumn{2}{|c|}{$\begin{array}{c}2010 \\
\text { Number } \\
\text { Percent of } \\
\text { All Households }\end{array}$} & \multicolumn{2}{|c|}{$\begin{array}{c}\text { Change in } \\
\text { Numbers, } 2000 \text { to } \\
2010 \\
\text { Number Percent } \\
\text { Change }\end{array}$} \\
\hline $\begin{array}{l}\text { Husband and Wife } \\
\text { Family Households } \\
\text { With Own Children }^{15} \\
\text { Without Own Children }\end{array}$ & $\begin{array}{l}54,493,232 \\
24,835,505 \\
29,657,727\end{array}$ & $\begin{array}{l}23.5 \\
28.1\end{array}$ & $\begin{array}{l}23,588,377 \\
32,922,268\end{array}$ & $\begin{array}{l}20.2 \\
28.2\end{array}$ & $\begin{array}{l}+2,017,145 \\
-1,247,237 \\
+3,246,382\end{array}$ & $\begin{array}{l}-5.0 \\
11.0\end{array}$ \\
\hline $\begin{array}{l}\text { Unmarried Couple } \\
\text { Households: } \\
\text { Opposite-Sex Partner } \\
\text { Same-Sex partner }\end{array}$ & $\begin{array}{r}4,881,377 \\
594,391\end{array}$ & $\begin{array}{l}4.6 \\
0.6\end{array}$ & $\begin{array}{r}6,842,714 \\
901,997\end{array}$ & $\begin{array}{l}5.9 \\
0.8\end{array}$ & $\begin{array}{r}+1,961,337 \\
+307,606\end{array}$ & $\begin{array}{l}40.2 \\
51.8\end{array}$ \\
\hline
\end{tabular}

In 2000, husband and wife households represented $51 \%$ of all households and $76 \%$ of family households. ${ }^{16}$ By 2010 , though, the number of husband and wife households increased by $4.7 \%$, but dropped to $48 \%$ of all households and $73 \%$ of family households. ${ }^{17}$

Unmarried couple households represented $5.2 \%$ of all households in 2000 and increased to $6.6 \%$ of all households by 2010. In 2000, opposite-sex partner households represented $4.6 \%$ of all households and $89 \%$ of unmarried-couple households. ${ }^{18}$ By 2010 , opposite-sex partner household rose by $40 \%$ in numbers and to $5.9 \%$ of all households and $88 \%$ of unmarried-couple households. ${ }^{19}$ Same-sex partner households represented $0.6 \%$ of all households and $11 \%$ of unmarried-partner households in $2000 .{ }^{20}$ By 2010, the number of same-sex partner households rose by $52 \%$ and to $0.8 \%$ of all

${ }^{12}$ Adapted from id. tbl. 2, at 3.

${ }^{13}$ The Census Bureau defines a "household" as consisting of "all of the people who occupy a housing unit." Id. at 2.

${ }^{14}$ The Census Bureau defines a "family household" as a household that consists of "a householder and one or more other people living in the same household who are related to the householder by birth, marriage, or adoption." Id. at 2.

${ }^{15}$ The Census Bureau defines "own children" as consisting of "biological, adopted, and stepchildren of the householder who are under 18." Id.

${ }^{16}$ See id. tbl. 2, at 3.

${ }^{17}$ See id.

${ }^{18}$ See id.

${ }^{19}$ See id.

${ }^{20}$ See id. 
Prepublication Draft: Marital Rights for Unmarried Partners?

households; they remained stable at $11 \%$ of unmarried-partner households. ${ }^{21}$

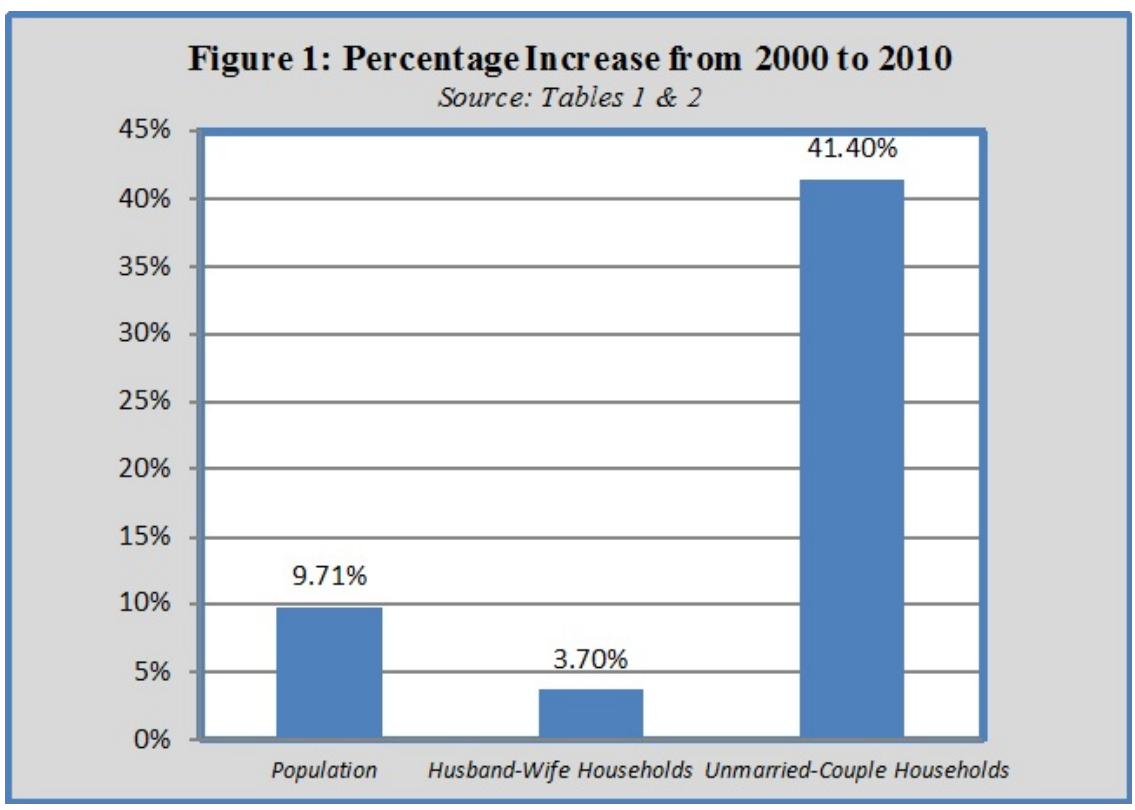

As illustrated by Figure 1, the population grew by $9.71 \%$ between 2000 and 2010. By contrast, the husband and wife households only grew by $3.7 \%$, but the unmarried couple households grew by $41.4 \%$. The husband and wife households also declined as a percentage of all households and of family households. ${ }^{22}$ Unmarried couple households, opposite-sex partner households, and same-sex partner households rose in both numbers and percentages of all households.

\footnotetext{
${ }^{21}$ See id.

${ }^{22}$ For the Census Bureau's definitions of "household" and "family household," see supra notes $14 \& 15$.
} 
Prepublication Draft: Marital Rights for Unmarried Partners?

\begin{tabular}{|c|c|c|}
\hline 9000000 & \multicolumn{2}{|c|}{$\begin{array}{c}\text { Figure 2: } 2000 \text { \& } 2010 \text { Unmarrieed Partners } \\
\text { Source: Table 2 }\end{array}$} \\
\hline $8,000,000$ & & $\begin{array}{l}901,997 \\
\text { Same }\end{array}$ \\
\hline 7000000 & & \\
\hline 6.000 .000 & 594,391 & \\
\hline & Same Sex & $6,842,714$ \\
\hline $4,000,000$ & & Sex \\
\hline $3,000,000$ & $4,881,377$ & \\
\hline & Opposite & \\
\hline & & \\
\hline & 2000 & 2010 \\
\hline
\end{tabular}

Figure 2 pictures the degree to which opposite-sex partner households outnumber same-sex partner households. ${ }^{23}$ Although the ratio dropped from 8.2 to 1 in 2000 to 7.6 to 1 in 2010, the ratio should widen as a certain percentage of same-sex couples shift to marriage.

Children are present in many unmarried couple households. In a report by a group of family scholars, the authors noted:

In the latter half of the twentieth century, divorce posed the biggest threat to marriage in the United States.... No More.... Today, the rise of cohabiting households with children is the largest unrecognized threat to the quality and stability of children's family lives.... Now, approximately 24 percent of the nation's children are

23 For more statistics, see Unmarried Equality, available at http://www.unmarried.org/statistics/. Unmarried Equality, formerly known as The Alternatives to Marriage Project, is an advocacy group for rights of the unmarried. According to their mission statement, "Unmarried Equality (UE) advocates for equality and fairness for unmarried people, including people who are single, choose not to marry, cannot marry, or live together before marriage.... Unmarried Equality is not opposed to marriage. But we believe that unmarried relationships also deserve validation and support." Unmarried Equality Mission Statement, available at http://www.unmarried.org/about-us/. 


\section{Prepublication Draft: Marital Rights for Unmarried Partners?}

born to cohabiting couples, which means that more children are currently born to cohabiting couples than to single mothers. ${ }^{24}$

Of all households counted in the 2010 census, 5.9\% were unmarried opposite-sex couple households and $2.3 \%$ were unmarried opposite-sex couple households with own children. ${ }^{25}$ Unmarried same-sex couple households made up $0.6 \%$ of all households, and those with own children $0.1 \%{ }^{26}$ Stated another way, $39 \%$ of unmarried opposite-sex couple households had own children present and $17 \%$ of unmarried same-sex couple households had own children present. $^{27}$

${ }^{24}$ W. BradFord WilcoX ET AL., Why MarRiage Matters 6 (3d ed. 2011). See also CHARLES MURRAY, COMING APART 169 ( $\left({ }^{\text {st }}\right.$ paperback ed. 2013) ("If you are interested in the welfare of children. knowing that the child was born to a cohabiting woman instead of a lone unmarried woman should have little effect on your appraisal of the child's chances in life."); Wendy D. Manning, Cohabitation and Child Wellbeing, 25 Marriage AND ChILD Well BeING 51 (Fall 2015),

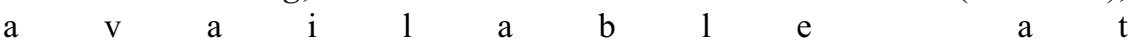
http://www.princeton.edu/futureofchildren/publications/docs/Cohabitation.pdf("On the other hand, stable cohabiting families with two biological parents seem to offer many of the same health, cognitive, and behavioral benefits that stable married biological parent families provide.").

${ }^{25}$ See U.S. Census Bureau, Households and Families: 2010, tbl.3, at 8 (April 2012), available at http://www.census.gov/prod/cen2010/briefs/c2010br-14.pdf.

${ }^{26}$ See id.

${ }^{27}$ By another count, $19 \%$ of same-sex couples are raising biological, step, or adopted children. See Gary J. Gates, The Williams Institute, UCLA School of Law, LGBT Parenting in the United States (Feb. 2013), available at http://williamsinstitute.law.ucla.edu/wp-content/uploads/LGBT-Parenting.pdf. There is a vast literature on children of same-sex couples. See, e.g., Catherine Smith, Equal Protection for Children of Same-Sex Parents, 90 WASH. U. L. REV. 1589 (2013); Courtney G. Joplin, Searching for Harm: Same-Sex Marriage and the Well-Being of Children, 46 HARV. C.R.-C.L.L. REV. 81 (2011); Jennifer L. Rosato, Children of Same-Sex Parents Deserve the Security Blanket of the Parentage Presumption, 44 FAM. CT. ReV. 74 (2006); Lewis A. Silverman, Suffer the Little Children: Justifying Same-Sex Marriage from the Perspective of a Child of the Union, 102 W. VA. L. REV. 411 (1999); Nancy D. Polikoff, For the Sake of All Children: Opponents and Supporters of Same-Sex Marriage Both Miss the Mark, 8 N.Y. City L. Rev. 573 (2005); Sam Castic, The Irrationality of a Rational Basis: Denying Benefits to the Children of Same-Sex Couples, 3 MoD. AM. 3 (2007).

$-10-$ 


\section{Prepublication Draft: Marital Rights for Unmarried Partners?}

\section{Impact of Same-Sex Marriage on the Marriage Rate}

The Supreme Court has now spoken. In Obergefell v. Hodges, ${ }^{28}$ the Court held that same-sex couples have a constitutional right to marry, saying:

$[\mathrm{T}]$ he right to marry is a fundamental right inherent in the liberty of the person, and under the Due Process and Equal Protection Clauses of the Fourteenth Amendment couples of the same-sex may not be deprived of that right and that liberty. The Court now holds that same-sex couples may exercise the fundamental right to marry. ${ }^{29}$

A Gallup Poll taken shortly before the Supreme Court decided Obergefell found that $60 \%$ of Americans support legalization of same-sex marriage; that figure is up from 55\% in 2014 and is the highest approval that Gallup has found on the question. ${ }^{30}$ One demographer found "no evidence that allowing same-sex couples to marry reduces the opposite-sex marriage rate." 31

Before Obergefell, same-sex marriage was legal in thirty-seven states and the District of Columbia. ${ }^{32}$ The movement toward

${ }^{28} 576$ U.S.__ _ Slip Opinion No. 14-556 (June 26, 2015).

${ }^{29} I d$. at 22. In Davis v. Miller (Aug. 31, 2015), No. 15A250, the Court denied a petition by a Kentucky county clerk to be allowed to refuse to issue marriage licenses on the ground of her religious beliefs against same-sex marriage.

${ }^{30}$ See Justin McCarthy, GalluP, Record-High 60\% of Americans Support Same-Sex Marriage, (May 18, 2015), available at http://www.gallup.com/poll/183272/record-high-americans-support-sex-marriage .aspx?utm_source $=$ Social\%20Issues\&utm_medium $=$ newsfeed\&utm_campaign $=\mathrm{t}$ iles. For a similar result, see Karlyn Bowman, AMERICAN ENTERPRISE INSTITUTE, Public Opinion on Same-Sex Marriage: Anatomy of a Change (June 1, 2015), $\begin{array}{lllllllllll}a & v & a & i & l & a & b & l & e & a & t\end{array}$ http://www.aei.org/publication/public-opinion-on-same-sex-marriage-anatomy-o f-a-change/.

${ }^{31}$ Marcus Dillender, The Death of Marriage? The Effects of New Forms of Legal Recognition on Marriage Rates in the United States, 51 DEMOGRAPHY 563, 563 (2014).

${ }^{32}$ For an exact time line, see NAT'L CONFERENCE OF STATE LEGISLATURES, $\begin{array}{lllllllllllllllllll}S & a & m & e & S & e & x & M & a & r & r & i & a & g & e & L & a & w & s\end{array}$, http://www.ncsl.org/research/human-services/same-sex-marriage-laws.aspx (last visited July 31,2015$)$. Internationally, twenty countries have legalized same-sex marriage: Ireland (2015), Finland (2015), Luxembourg (2014), Scotland (2014),

$-11-$ 


\section{Prepublication Draft: Marital Rights for Unmarried Partners?}

legalization started with the 2003 decision of the Supreme Judicial Court of Massachusetts in Goodridge v. Dep't of Public Health.$^{33} \mathrm{In}$ twenty-five of the thirty-seven states, same-sex marriage was legalized by state or federal judicial decision, ${ }^{34}$ eleven and the District of Columbia by legislation, ${ }^{35}$ and one by state voter approved ballot proposal. ${ }^{36}$ Based on Census 2010 data, the Census Bureau initially estimated that $25.6 \%$ of same-sex partners were married, but later issued a lower revised estimate of $20 \% .{ }^{37}$ In terms of numbers, the Census Bureau initially estimated that there were 251,695 same-sex married couples in 2013, but later revised its estimate downward, finding the number to be 170,429 ; the discrepancy was attributed to opposite sex married couples checking the wrong gender box by mistake on the survey questionnaire. ${ }^{38}$ Because these figures were

England and Wales (2013), Brazil (2013), France (2013), New Zealand (2013), Uruguay (2013), Denmark (2012), Argentina (2010), Portugal (2010), Iceland (2010), Sweden (2009), Norway (2009), South Africa (2006), Spain (2005), Canada (2005), Belgium (2003), and The Netherlands (2000). In Mexico, Mexico City (2009) and the states of Quintana Roo (2011) and Coahuila (2014) have legalized same-sex marriage. See PEW RESEARCH CENTER, Gay Marriage Around the World

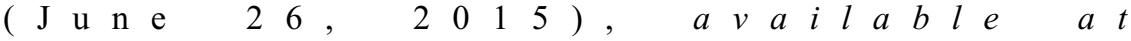
http://www.pewforum.org/2015/06/26/gay-marriage-around-the-world-2013/?ut $\mathrm{m}$ _source $=$ Pew + Research + Center\&utm_campaign $=1$ e18492f80-Same_sex_deci sion_newsletter_June_266_26_2015\&utm_medium $=$ email\&utm_term $=0$ _3e 953 b9b70-1e18492f80-399818005.

33798 N.E.2d 941 (Mass. 2003).

${ }^{34}$ Alaska, Alabama, Arizona, California, Colorado, Florida, Idaho, Indiana, Iowa, Kansas, Massachusetts, Montana, New Mexico, New York, New Jersey, Nevada, North Carolina, Oklahoma, Pennsylvania, South Carolina, Utah, Virginia, West Virginia, Wisconsin, and Wyoming. See NAT'L Conference of State LegisLATURES, Same-Sex Marriage Laws, supra note 32.

35 Connecticut, Delaware, Hawaii, Illinois, Maryland, Minnesota, New Hampshire, New York, Rhode Island, Vermont, Washington. See id.

${ }^{36}$ Maine. See id.

${ }^{37}$ See U.S. Census Bureau, Census Bureau Releases Estimates of Same-Sex Married Couples, Sept. 27, 2011, available at http://www.census.gov/newsroom/releases/archives/2010_census/cb11-cn181.html.

38 See Daphne Lofquist, Social, Economic, AND Housing STATiSTiCs Division, U.S. CENSUS BUREAU, Using Names to Improve Measurement of Samesex Married Couples in the American Community Survey, at $9 \&$ tbl.4 at 15 (2015), $\begin{array}{lllllllllll}a & v & a & i & l & a & b & l & e & a\end{array}$ http://www.census.gov/content/dam/Census/library/working-papers/2015/demo/2 015-Lofquist-01-Abstract.pdf. See also D'Vera Cohn, PEW ReSEARCH CENTER, 


\section{Prepublication Draft: Marital Rights for Unmarried Partners?}

compiled when same-sex marriage was becoming more available but not yet universally available (as it is as of June 26, 2015), the figures might not be a reliable predictor of the long-term marriage or nonmarriage habits of same-sex partners.

\section{The Benefits, Rights, and Obligations of Marriage}

Marriage carries significant psychological, ${ }^{39}$ health, ${ }^{40}$ and financial ${ }^{41}$ benefits. Marriage also creates federal and state rights, obligations, and immunities ${ }^{42}$ - including social security, ${ }^{43}$ taxation, ${ }^{44}$

How many same-sex married couples in the U.S.? Maybe 170,000 (June 24, 2015), $\begin{array}{llllllllll}a & v & a & i & l & a & b & l & e & a\end{array}$ http://www.pewresearch.org/fact-tank/2015/06/24/how-many-same-sex-marriedcouples-in-the-u-s-maybe-170000/?utm_source=Pew + Research + Center\&utm_ca mpaign=6f9a4ee826-June_25_2015_Newsletter6_24_2015\&utm_medium=emai $1 \& u t m \_t e r m=0 \_3 e 953 b 9 b 70-6 f 9 a 4 e e 826-399818005$.

${ }^{39}$ See, e.g., The Heritage Foundation, The Benefits of Marriage, Family

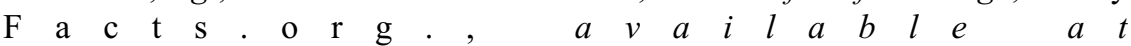
http://www.familyfacts.org/briefs/1/the-benefits-of-marriage.

${ }^{40}$ See, e.g., id; Michael S. Rendall et al., The Protective Effect of Marriage for Survival: A Review and Update, 48 DEMOGRAPHY 481 (2011) ("[W]e find a consistent survival advantage for married over unmarried men and women, and an additional survival 'premium' for married men."); Andrew Hess \& Glenn T. Stanton, The Health Benefits of Marriage (Sept. 2012), available at http:/www.focusonthefamily.com/about_us/focus-findings/marriage/health-bene fits-of-marriage.aspx.

${ }^{41}$ See, e.g., Jonathan Vespa \& Matthew A. Painter II, Cohabitation History, Marriage, and Wealth Accumulation, 48 DEMOGRAPHY 983 (2011) ("Over time, marriage positively correlates with wealth accumulation."); Lisen Stromberg, What's Love Got to Do With It? The Financial Benefits of Marriage, Money Under 30, available at http://www.moneyunder30.com/financial-benefits-of-marriage; Nolo, Marriage Rights and Benefits, NOLO, available at http://www.nolo.com/legal-encyclopedia/marriage-rights-benefits-30190.html.

${ }^{42}$ In Obergefell, 576 U.S.___ (June 26, 2015), Slip Opinion No. 14-556, at 12, the Supreme Court listed the benefits and obligations of marriage as including "taxation; inheritance and property rights; rules of intestate succession; spousal privilege in the law of evidence; hospital access; medical decisionmaking authority; adoption rights; the rights and benefits of survivors; birth and death certificates; professional ethics rules; campaign finance restrictions; workers' compensation benefits; health insurance; and child custody, support, and visitation rules."

${ }^{43}$ See Social SECURITY ADMINISTRATION, Social Security Survivor Benefits 5, available at http://www.socialsecurity.gov/pubs/EN-05-10084.pdf.

44 Joint income tax return (I.R.C. $\S 1(\mathrm{a})$ ) and estate and gift tax marital deduction (I.R.C. $\S \S 2056,2523$ ). The income tax, however, also has marriage penalties. See CONGRESSIONAL BUdGET OFFICE, For Better or Worse: Marriage and 
Prepublication Draft: Marital Rights for Unmarried Partners?

spousal-communication-and-testimonial-privileges, ${ }^{45}$ obligation of support, ${ }^{46}$ the right to a property settlement and perhaps alimony in divorce, ${ }^{47}$ a large intestate share for a surviving spouse, ${ }^{48}$ and protection against disinheritance via a right to elect a forced share. ${ }^{49}$ In community property states, property acquired during marriage other than by gift or inheritance is community property and is owned

the Federal Income Tax (June 1997), available at https://www.cbo.gov/sites/default/files/105th-congress-1997-1998/reports/marria ge.pdf. The Tax Policy Center offers a Marriage Tax Calculator. See TAX POLICY CENTER, Marriage Bonus and Penalty Tax Calculator, available at http://taxpolicycenter.org/taxfacts/marriagepenaltycalculator.cfm. Obtaining a divorce for the sole purpose of filing tax returns as unmarried individuals is forbidden if, at the time of the divorce, the divorced individuals intend to and do remarry in the next tax year. See I.R.S. Pub. No. 17 at 20.

${ }^{45}$ See, e.g., CALIF. EVID. CODE $§ 970$ (privilege not to testify against spouse); $i d . \S 971$ (privilege not to be called as a witness against spouse).

${ }^{46}$ See, e.g., 750 ILL. COMP. STAT. 15/16.

47 See e.g., Mich. COMP. Laws $\S \S 552.101-.103$. See generally Ira Mark Ellman, The Theory of Alimony, 77 CAL. L. REV. 1 (1989).

${ }^{48}$ See, e.g., UNIF. Probate CODE § 2-102.

A few states, by statute, bar the surviving spouse from taking for desertion or adultery. See KY. REV. STAT. ANN. §392.090 (spouse barred if spouse "leaves the other and lives in adultery," unless the spouses "afterward become reconciled and live together as husband and wife"); N.H. REV. STAT. ANN. § 560:19 (spouse barred "if at the time of the death of either husband or wife, the decedent was justifiably living apart from the surviving husband or wife because such survivor was or had been guilty of conduct which constitutes cause for divorce"); N.Y. EST. POWERS \& TRUSTS LAW § 5-1.2(5), (6) (spouse barred if spouse "abandoned the deceased spouse, and such abandonment continued until the time of death" or if the spouse "who, having the duty to support the other spouse, failed or refused to provide for such spouse though he or she had the means or ability to do so, unless such marital duty was resumed and continued until the death of the spouse having the need of support"); 20 PA. CONS. STAT. ANN. § 2106(a) (spouse barred "who, for one year or upwards previous to the death of the other spouse, has wilfully neglected or refused to perform the duty to support the other spouse, or who for one year or upwards has wilfully and maliciously deserted the other spouse"); VA. CODE ANN. $\S 64.1-16.3 \mathrm{~A}$ (spouse barred if spouse "wilfully deserts or abandons his or her spouse and such desertion or abandonment continues until the death of the spouse").

A few courts, without statutory authority to vary the rights provided to surviving spouses, have denied claims against decedents' estates by persons who were lawfully married to the decedents when they died. See, e.g., Estate of Abila, 197 P.2d 10 (Cal. 1948) (wife barred because interlocutory decree of divorce, granted to decedent before his death, terminated decedent's obligation of support, though it did not dissolve the marriage).

${ }^{49}$ See, e.g., UnIF. PROBATE CODE $\S \S 2-201$ to 2-214. 


\section{Prepublication Draft: Marital Rights for Unmarried Partners?}

fifty-fifty by each married partner. Under Obergefell, these benefits are now available in all states and in most and perhaps all U.S. Territories ${ }^{50}$ to same-sex couples who decide to get married, ${ }^{51}$ not just in the thirty-seven states in which same-sex marriage had previously been legalized.

Pre-Obergefell, several states in which same-sex marriage was prohibited provided mechanisms by which same-sex couples could gain most or all state but not federal marital benefits by registering as domestic partners or as reciprocal beneficiaries or by entering into civil unions. ${ }^{52}$ The Census Bureau estimated that, as of 2010, 169,205

${ }^{50}$ See Omar Gonzalez-Pagan, No Same-Sex Couple Left Behind: SCOTUS Ruling for the Freedom to Marry would Apply with Equal Force to U.S. Territories, A p r i $24, \quad 2015, \quad a v a i l a b l e \quad a t$ http://www.lambdalegal.org/blog/20150424_scotus-ruling-would-apply-to-us-ter ritories. The five U.S. Territories are Puerto Rico, the U.S. Virgin Islands, Guam, the Northern Mariana Islands, and American Somoa. Individuals born in American Somoa, unlike individuals born in the other four territories, are not U.S. citizens; they are U.S. nationals. See id. The equal protection and due process clause of the 14trh Amendment of the U.S. Constitution applies to "citizens of the United States." U.S. CONST. amend. XIV, $\S 1$.

${ }^{51}$ Regarding federal benefits, see U.S. DEP'T OF JustiCE, Attorney General Lynch Announces Federal Marriage Benefits Available to Same-Sex Couples Nationwide (Press Release July 9, 2015), available at $\mathrm{http} / / / \mathrm{www}$.justice.gov/opa/pr/attorney-general-lynch-announces-federal-marriag e-benefits-available-same-sex-couples; SOCIAL SECURITY ADMINISTRATION, Supreme Court Decision Regarding Same-Sex Marriage (July 9, 2015), available $a$

http://blog.socialsecurity.gov/2015/07/09/supreme-court-decision-regarding-sam e-sex-marriage/; Rev. Rul.2013-17, I.R.B. 2013-38. Regarding state and federal benefits, see Tara Siegel Bernard, What the Same-Sex Marriage Decision Means for Couples' Rights and Benefits, N.Y. TIMES, June 14, 2015, updated June 26,

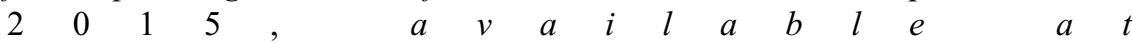
http://www.nytimes.com/2015/06/15/your-money/the-same-sex-marriage-decisio n-whats-at-stake-for-couples.html?_r=0.

${ }^{52}$ For a list of states, see NAT'L CONFERENCE OF STATE Legislatures, Civil Unions \& Domestic Partnership Statutes(Nov. 18, 2014), http://www.ncsl.org/research/human-services/civil-unions-and-domestic-partners hip-statutes.aspx. Some of the domestic-partner statutes allowed some or all opposite-sex couples to register as well. For federal tax purposes, civil unions, domestic partnerships, and other similar formal relationships are not marriages, because state law does not "denominate [these relationships] as ... marriage[s]." See Rev. Rul.2013-17, I.R.B. 2013-38. 


\section{Prepublication Draft: Marital Rights for Unmarried Partners?}

same-sex couples had done so. ${ }^{53}$ Shortly after Connecticut, Delaware, New Hampshire, and Rhode Island legalized same-sex marriage, those states enacted legislation that automatically converts thenexisting civil unions into marriages, ${ }^{54}$ instantly entitling the parties to all federal and state marital benefits. ${ }^{55}$

Because marriage has now become available to all same-sex couples and marriages in one state must now be recognized in all states, and because of the one-time conversion to marriage of civilunion couples, the overall marriage rate is certain to rise, ${ }^{56}$ but how substantial the long-term boost will be is hard to predict. ${ }^{57}$ The latest data on the overall marriage-rate and for the number of unmarried same-sex partners are for $2010 .{ }^{58}$ Since same-sex marriage began to become available in Massachusetts in 2003, and had become increasingly available even before Obergefell, ${ }^{59}$ the number of marriages represented in Table 1 from 2003 forward included some same-sex marriages, but the exact numbers for each year are not known. If all of the unmarried same-sex partners could have and had gotten married in 2010, an unlikely event, the marriage rate would have risen sharply, from $0.67 \%$ to $0.97 \% .^{60}$ It is predictable that Obergefell will unleash a degree of pent-up demand and that a

\footnotetext{
${ }^{53}$ See Daphne Lofquist, U.S. CENSUS BuREAU, Same-Sex Couple Households, tb1. 1 a t 3 ( S e p t. 2011$), \quad$ available at http://www.census.gov/prod/2011pubs/acsbr10-03.pdf.

${ }^{54}$ See Civil Unions \& Domestic Partnership Statutes, supra note 52.

${ }^{55}$ See supra notes 39-49.

${ }^{56}$ See Civil Unions \& Domestic Partnership Statutes, supra note 52.

${ }^{57}$ See Martha M. Ertman, Marital Contracting in a Post-Windsor World, 42 Fla. St. U. L. REV. 479, 482 (2015) ("Heterosexual practices are likely to be the most accurate predictor of changes in marriage and the legal rules governing it.").

${ }^{58}$ See supra Tables 1 and 2. See also Hunter Schwarz, Married Same-Sex Couples Make up less than One Half of One Percent of All Married Couples in the U.S., Sept. 22, 2014 , WASH. PosT, available at $\mathrm{http} / / / \mathrm{www}$.washingtonpost.com/blogs/govbeat/wp/2014/09/22/married-same-se $\mathrm{x}$-couples-make-up-less-than-one-half-of-one-percent-of-all-married-couples-in- $t$ he-u-s/.

${ }^{59}$ See Same Sex Marriage Laws, supra note 32.

${ }^{60}$ As shown in Table 2, there were 901,997 unmarried same-sex partner households in 2010. If all the partners had gotten married, there would have been $2,997,997$ marriages in a population of 308,745,538 instead of the actual number of marriages of 2,096,000 (see supra Table 1).
}

$-16-$ 


\section{Prepublication Draft: Marital Rights for Unmarried Partners?}

percentage of unmarried partners will get married in the wake of the Supreme Court's decision. ${ }^{61}$ If so, the rise in the marriage rate would likely be a one- or maybe two-year phenomenon and then level off. Once the pent-up demand has been fulfilled, the marriage habits of same-sex couples might, over time, turn out to be similar to the marriage habits of opposite-sex couples: If so, some will get married, some will break up, and some will continue to cohabit without getting married. $^{62}$

${ }^{61}$ See, e.g., Frank Bruni, Gay Marriage's Moment, N.Y. TIMES, June 21, 2015,

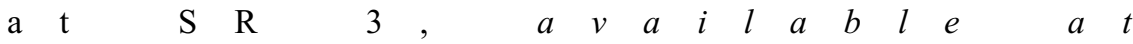
http://www.nytimes.com/2015/06/21/opinion/sunday/frank-bruni-gay-marriagesmoment.html action $=$ click\&pgtype $=$ Homepage $\&$ module $=$ opinion-c-col-right-re gion\&region=opinion-c-col-right-region $\& W T . n a v=$ opinion-c-col-right-region \&_ $\mathrm{r}=0$.

${ }^{62}$ See, e.g., Curtis Sittenfeld, Wedded Bliss for Everyone!, N.Y. TIMES, June 28,2015 , at SR8 ("Now that same-sex marriage is legal nationwide, plenty of gay people won't get married just because they can, just as plenty of straight people don't."), available electronically under the title Welcome, Everyone, to the Right to $\begin{array}{lllll}M & a & r & r & y\end{array}$, http://www.nytimes.com/2015/06/28/opinion/sunday/welcome-everyone-to-the-r ight-to-marry.html?action=click\&pgtype $=$ Homepage\&version=Moth-Visible\&m odule=inside-nyt-region\&region=inside-nyt-region $\& W T$.nav=inside-nyt-region $\& \_\mathrm{r}=0$. 


\section{Prepublication Draft: Marital Rights for Unmarried Partners?}

\section{E. Longer-Term Cohabitations}

Longer-term cohabiting couples are far from homogeneous. ${ }^{63}$ No one-size-fits-all generalization explains why a certain percentage of cohabiting couples continue to cohabit without getting married. ${ }^{64}$ In some cases, the couple has reached a joint decision not to marry, but

${ }^{63}$ For demographic information on cohabiting couples, see William G. Axinn \& Arnold Thornton, The Relationship Between Cohabitation and Divorce: Selectivity or Causal Relationship, 29 DEMOGRAPHY 357 (1992); Larry L. Bumpass, What's Happening to the Family? Interactions Between Demographic and Institutional Change, 27 DEMOGRAPHY 483 (1990); Larry L. Bumpass, National Estimates of Cohabitation, 26 DEMOGRAPHY 615 (1989); Larry L. Bumpass et al., The Role of Cohabitation in Declining Rates of Marriage, Working Paper No. 5 (Nat'1 Survey of Families and Households, 1989); Casey E. Copen et al., First Premarital Cohabitation in the United States: 2006-2010 Nat'1 Survey of Family Growth, Center for Disease Control, Nat'l Health Statistics Rep. No. 64 (April 4, 2013), available at http://www.cdc.gov/nchs/data/nhsr/nhsr064.pdf; Marcus Dillender, The Death of Marriage? The Effects of New Forms of Legal Recognition on Marriage Rates in the United States, 51 DEMOGRAPHY 563 (2014); Catherine T. Kenney \& Sara S. Mclanahan, Why Are Cohabiting Relationships More Violent than Marriages?, 43 DEMOGRAPHY 127 (2006); Lee A. Lillard et al., Premarital Cohabitation and Subsequent Marital Dissolution: A Matter of Self Selection, 32 Demography 437 (1995); Martin O'Connell \& Sarah Feliz, Same-sex Couple Household Statistics from the 2010 Census, U.S. Bureau of the Census

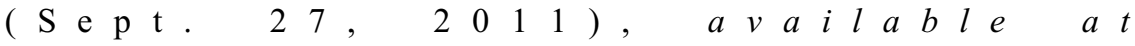
http://www.bing.com/search?q=O\%27Connell $\% 2 \mathrm{C}+$ same-sex+Household + Statis tics + from + the $+2010+$ Census \&qs $=$ n $\&$ form $=Q B R E \& p q=0 \% 27$ connell $\% 2 C+$ sam e-sex + household + statistics + from + the $+2010+$ census $\& \mathrm{sc}=0-0 \& \mathrm{sp}=-1 \& \mathrm{sk}=\& \mathrm{cvid}$ $=7020 \mathrm{baa} 6 \mathrm{a} 68 \mathrm{~d} 489$ eaeefc019df3f6dc0; Pew Research Center, Living Together: The Economics of Cohabitation (June 27, 2011), available at http://www.pewsocialtrends.org/files/2011/06/pew-social-trends-cohabitation-06 -2011.pdf; Stephen Reinhold, Reassessing the Link Between Premarital Cohabitation and Marital Instability, 47 DEMOGRAPHY 719 (2010); James A. Sweet \& Larry L. Bumpass, Disruption of Marital and Cohabitation Relationships: A Social-Demographic Perspective, Working Paper No. 32 (Nat'l Survey of Families and Households, 1990); Arland Thornton, Cohabitation and Marriage in the 1980s, 25 DEMOGRAPHY 497 (1988); Jonathon Vespa, Union Formation in Later Life: Economic Determinants of Cohabitation and Remarriage Among Older Adults, 49 DEMOGRAPHY 1103 (2012).

${ }^{64}$ See Ann Laquer Estin, Ordinary Cohabitation, 76 Notre Dame L. Rev. 1381, 1386-91 (2001); Clare Huntington, Postmarital Family Law: A Legal Structure for Nonmarital Families, 67 STAN. L. REV. 167, 185-96 (2015); Elizabeth S. Scott \& Robert E. Scott, From Contract to Status: Collaboration and the Evolution of Novel Family Relationships, Colum. Pub. L. \& Legal Theory Working Paper No. 14-409, at 62-63 (Aug. 2014), available at http://ssrn.com/abstract=2483430.

$-18-$ 


\section{Prepublication Draft: Marital Rights for Unmarried Partners?}

in other cases one wants to get married but the other resists. ${ }^{65}$ In still others, economic circumstances may dictate or influence the outcome. ${ }^{66}$ Many other factors can play a role as well. ${ }^{67}$ An unfortunate feature of some cohabiting couples is that they are at or below the poverty level: ${ }^{68}$ "As compared with their married counterparts, unmarried parents are lower income, less educated, disproportionately nonwhite, and more likely to have children from multiple partners." ${ }^{69}$ For many of them, they "have not selected their situation, they have settled for it."

Regardless of the reason for the continuation of the cohabitation, the couple, as unmarried partners, lack marital status and hence the automatic rights granted to spouses and surviving spouses. As far as the law is concerned, the partners are complete strangers to one another.

The rapid rise in cohabitation rates is well documented. Table 2 shows the rise from 5.48 million in 2000 to 7.74 million in 2010 . Earlier estimates by the Census Bureau put the number at about 1 million in 1977, 1.7 million in 1980, and 3 million in $1990 .{ }^{71}$

In a survey conducted in 2010, the Pew Research Center found that public attitudes widely differ by age groups: "Most adults ages 65 and older are critical of these unmarried couples, whether they are same-sex or opposite-sex couples. Most young adults, ages 18 to 29, are not., 72

${ }^{65}$ See Estin, supra note 64.

${ }^{66}$ See id.

${ }^{67}$ See id;

${ }^{68}$ See id. at 1388; MARRIAGE IN AMERICA, supra note 10, at 76 ("Cohabitation is more common among those of lower educational and income levels.").

${ }^{69}$ Huntington, supra note 64 at 186-87.

${ }^{70}$ Ira Mark Ellman, Marital Roles and Declining Marriage Rates, 41 FAM. L.Q. 455, 485 (2007)

${ }^{71}$ See Lynne M. Casper et al., Population Division, U.S. CEnsus Bureau, How Does POSSLQ Measure Up? Historical Estimates of Cohabitation, Population Div. Working Paper No. 36, at tbl. 1, (May 1999), available at http://www.census.gov/population/www/documentation/twps0036/twps0036.html..

${ }^{72}$ Pew: The Decline of Marriage \& Rise of New Families, supra note 6, at 64. 


\section{Prepublication Draft: Marital Rights for Unmarried Partners?}

Although at the current time, only $9.1 \%$ of Americans women age 15 to 44 are cohabiting, ${ }^{73}$ the percentage is higher at the younger ages. In the age 20 to 24 category, $15.7 \%$ are cohabiting, and in the 25 to 29 year category, the percentage is $12.9 .{ }^{74}$ As might be expected, the rates are lower for middle-aged and older people: age 30 to $34,7.9 \%$, age 35 to $39,6.7 \%$, and age 40 to $44,6.6 \%{ }^{75}$

The most important statistic for spousal-rights law is that for most people cohabitation is a temporary or short-term state. The parties either break up or get married fairly quickly. By about one and onehalf years, half the cohabiting couples have either married or broken up. Only about ten percent remain cohabiting after five years. ${ }^{76}$ This does not mean, however, that at any point in time there are only a few longer-term cohabitations. The longer-term cohabitations tend to accumulate in the population. More are added every year.

73 See Paula Y. Goodwin et al., CENTER FOR DiSEASE CONTROL AND Prevention, Marriage and Cohabitation in the United States: A Statistical Portrait Based on Cycle 6 (2002) of the National Survey of Family Growth tbl. 1 at 17 ( Vital and Health Statistics Series 23, no. 28, Feb. 2010), available at http://www.cdc.gov/nchs/data/series/sr 23/sr23 028.pdf.

${ }^{74}$ See id.

75 See id.

${ }^{76}$ See Casey E. Copen et al., CEnTER for Disease Control, NAT'L CENTER FOR HEALTH StATISTICS, First Premarital Cohabitation in the United States: 20062010 National Survey of Family Growth, Report No. 64, at 5 (April 4, 2013), available at http://www.cdc.gov/nchs/data/nhsr/nhsr064.pdf; NAT'L CENTER FOR Health Statistics, Centers for Disease Control and Prevention, Marriage and Cohabitation in the United States: A Statistical Portrait Based on Cycle 6 (2002) of the National Survey of Family Growth, at 1 (Series 23 No. 28, Feb. 2010), available at http://www.cdc.gov/nchs/data/series/sr_23/sr23_028.pdf; NAT'L Center for Health Statistics, Centers for Disease Control AND Prevention, Cohabitation, Marriage, Divorce, and Remarriage in the United States 12 (Series 23 No. 22, July 2002), available at http://www.cdc.gov/nchs/data/series/sr_23/sr23_022.pdf. 


\section{Prepublication Draft: Marital Rights for Unmarried Partners?}

\section{CASE LAw: From CONTRACT TO Status ${ }^{77}$}

\section{A. Recovery Based on Contract}

The longer-term cohabitations are the ones that tend to find their way into the legal system. Law suits are brought upon disinheritance at death or, more commonly, the deliberate decision of one of the parties to terminate the relationship. The unmarried-cohabitors cases that come to public attention nearly always involve a defendant who is a wealthy celebrity, entertainer, or professional athlete. But the less celebrated come to court also. As a Houston divorce attorney once remarked: "You don't need millions of dollars for people to fight. Give two people a house worth $\$ 200,000$ and they'll consider an action." ${ }^{.78}$

These suits are sometimes grounded on a common-law marriage claim, but when that claim is unavailable because the state does not recognize common-law marriages ${ }^{79}$ or because the arrangement does not fit within the common-law marriage criteria, the suits can still go forward as ones for "palimony." ${ }^{" 00}$ Not surprisingly, most of the cases arise in the context of a dissolution during life. Claims arising at death are less common because, if the partners remain devoted to one another, the surviving partner might be provided for in the decedent's will or other parts of the estate plan. ${ }^{81}$ Therefore, it is less usual for

${ }^{77}$ Portions of the discussion in Part II draw upon an earlier article: Lawrence W. Waggoner, Marital Property Rights in Transition, 59 Mo. L. REV. 21, 61-78 (1994).

${ }^{78}$ Gary Taylor, Increased Mobility Adds to Common Law Claims, NAT'L L.J., Aug. 14, 1989, at 24. According to the Bureau of Labor Statistics CPI inflation calculator, $\$ 200,000$ in 1989 would be $\$ 385,000$ in real dollars in 2015 .

79 See infra Part II.B.1.

${ }^{80}$ The term "palimony" is misleading, because the plaintiff is usually seeking a division of the couple's property, not an award of periodic payments similar to alimony.

${ }^{81}$ In speaking of the power of testation, Jeremy Bentham noted that "a man should have the means of cultivating the hopes and rewarding the care of ... a woman who, but for the omission of a ceremony, would be called his widow ...." JEREMY BENTHAM, THE THEORY OF LEGISLATION 185-86 (C.K. Ogden ed., 1931).

See generally, however, Joseph W. deFuria Jr., Testamentary Gifts Resulting from Meretricious Relationships: Undue Influence or Natural Beneficence?, 64 Notre DAME L. REV. 200 (1989) (“"Although only] a few courts [raise] a rebuttable presumption of undue influence ... whenever the testator willed his estate to a meretricious partner ... [m] any more courts emphasized that such a relationship 


\section{Prepublication Draft: Marital Rights for Unmarried Partners?}

cases to arise in which a surviving partner is making a claim to a share of a decedent's estate, but such cases do arise. ${ }^{82}$

raised a significant suspicion of undue influence, which would be closely scrutinized."); Jeffrey G. Sherman, Undue Influence and the Homosexual Testator, 42 U. PITT. L. REV. 225 (1981) ("[T]here is at least some evidence to suggest that a homosexual testator who bequeaths the bulk of his estate to his lover stands in greater risk of having his testamentary plans overturned than does a heterosexual testator who bequeaths the bulk of his estate to a spouse or lover."); Jane Birnbaum, Gay Partners' Problem: Passing on Their Assets, N.Y. TimES, Jan. 15, 1994, at 31 ("Propelled in part by the AIDS epidemic, gay men and lesbians increasingly look to revocable living trusts as a way to efficiently pass on assets to their partners and to insure their partners will handle their personal affairs if they become incapacitated.... Because the trusts generally avoid probate and are unpublished, the deceased's family is less likely to intervene than with a will."); Annot., Existence of Illicit or Unlawful Relation Between Testator and Beneficiary as Evidence of Undue Influence, 76 A.L.R.3d 743 (1977).

${ }^{82}$ Although most of the cases have involved property disputes between living cohabitors who have separated, some cases have involved contractual or equitable claims by the survivor to a share of the other's estate upon the latter's death. Complaints founded upon breach of oral promises supported by social, domestic, nursing, and business services have been held to state a cause of action. See, e.g., Poe v. Estate of Levy, 411 S.2d 253 (Fla. Ct. App. 1982) (reversing trial court's dismissal of count seeking enforcement of an express support contract and count seeking imposition of a constructive trust in certain property due to a confidential relationship between surviving cohabitor and decedent, but affirming trial court's dismissal of count seeking one-half ownership interest in decedent's property grounded on argument that their relationship had the same force and effect as a legal marriage); Donovan v. Scuderi, 443 A.2d 121 (Md. Ct. Spec. App. 1982) (plaintiff entitled to recover damages for breach of express oral promise to pay to plaintiff 1,000 shares of stock of the bank of which the decedent was chairman of the board, in return for which plaintiff made various expenditures and provided loans and services, including "catering services, personal shopping services, clothing, furniture and furnishings;" decedent, a married man, and plaintiff, an unmarried woman, did not have a full-time cohabitation relationship, but frequently used an apartment plaintiff had obtained at decedent's request); Tyranski v. Piggins, 205 N.W.2d 595 (Mich. Ct. App. 1973) (surviving cohabitor entitled to specific performance of decedent's oral promise to convey house to her; plaintiff, a married woman who was separated from her husband, performed various domestic, social, and nursing services for decedent).

Complaints have also been held to state a cause of action when they sought the imposition of a constructive trust on specific property based on a confidential relationship between the cohabitors. See, e.g., Poe, 411 So.2d at 256. Complaints seeking damages in the amount of the value of such services on the theory of quantum meruit (as much as the plaintiff deserved) have also been upheld. See, e.g., Green v . Richmond, 337 N.E.2d 691 (Mass. 1975) (surviving cohabitor entitled to quantum meruit recovery of damages for value of social, domestic, and business services performed in reliance on decedent's oral promise to leave a will devising 


\section{Prepublication Draft: Marital Rights for Unmarried Partners?}

Plaintiffs seem to have no problem in stating a cause of action when they allege that they made a financial contribution toward the purchase of specific property on the understanding that they would be the owner or part owner. The fact that the property was not titled in the plaintiff's name is not a defense. A cause of action for the imposition of a purchase-money resulting trust or a constructive trust on the specific property is well established. ${ }^{83}$

But what if the plaintiff's contribution came in the form of domestic services? The case that has received the most notoriety is Marvin v. Marvin. ${ }^{84}$ The Marvin case was one of the first cases to confront the problem of remedy in a domestic-services case.

The Restatement of Restitution and Unjust Enrichment provides for an equitable remedy in the case of uncompensated contributions in the form of property or services:

$\S 28$. Unmarried Cohabitants.... If two persons have formerly lived together in a relationship resembling marriage, and if one of them owns a specific asset to which the other has made substantial, uncompensated contributions in the form of property or services, the person making such contributions has a claim in restitution

his entire estate to her; Humiston v. Bushnell, 394 A.2d 844 (N.H. 1978) (lack of proof of alleged oral promise to devise a certain parcel of realty prevented surviving cohabitor from recovering damages for breach; surviving cohabitor was entitled to recover in quantum meruit for value of "intimate, confidential, and dedicated personal and business service" she performed for the decedent with the expectation of being ultimately compensated therefor); Estate of Steffes, 290 N.W.2d 697 (Wis. 1980) (surviving cohabitor entitled to recover damages for value of housekeeping, farming, and nursing services rendered at decedent's request and with the expectation of being compensated therefor).

Also, complaints seeking the imposition of an implied partnership with respect to a business arrangement have been upheld. See, e.g., Estate of Thornton, 499 P.2d 864 (Wash. 1972) (surviving cohabitor entitled to recover on basis of an implied partnership in cattle-raising business). But the dismissal of a complaint seeking a half interest in the decedent's property based on the theory that the parties' relationship had the same force and effect as a legal marriage was affirmed. See, e.g., Poe, 411 So.2d at 256.

83 See, e.g., Estate of Eriksen, 337 N.W.2d 671 (Minn. 1983) (surviving cohabitor entitled to constructive trust in her favor of a one-half interest in home purchased with joint funds but titled in decedent's name alone).

${ }^{84} 557$ P.2d 106 (Cal. 1976). 


\section{Prepublication Draft: Marital Rights for Unmarried Partners?}

against the owner as necessary to prevent unjust enrichment upon the dissolution of the relationship. ${ }^{85}$

Nevertheless, with respect to domestic services, the Restatement states that "[c]laims to restitution based purely on domestic services are less likely to succeed, because services of this character tend to be classified among the reciprocal contributions normally exchanged between cohabitants whether married or not."

In consequence, unmarried cohabitors who contribute domestic are entering into a much riskier venture than partners entering into marriages with similar divisions of labor. Those entering into marriages with similar divisions of labor have the divorce laws and the intestacy and elective-share or community-property laws as backup protection. Those entering such a relationship without marriage have virtually no legal rights to fall back on.

What can they do to protect themselves? One thing they can do is to insist on protection by contract. The reality is, however, that in many of the litigated cases, there is a disparity of bargaining power. By being older and already wealthy, one party is often in a dominant position. For this reason, and because bargaining is done in the shadow of one's legal rights and the unmarried have virtually no back-up legal rights, the other party is in a "subordinate" position. ${ }^{87}$ If there is to be a contract, a written contract, as required in two

85 Restatement OF RESTITUTION AND UnJUST ENRICHMENT $§ 28$ (2011). Section 28 also provides that the rule of this section "may be displaced, modified, or supplemented by local domestic relations law."

${ }^{86} \mathrm{Id}$. at cmt. d.

${ }^{87}$ Cf. Robert H. Mnookin \& Lewis Kornhauser, Bargaining in the Shadow of the Law: The Case of Divorce, 88 YALE L.J. 950, 968 (1979):

Divorcing parents do not bargain over the division of family wealth and custodial prerogatives in a vacuum; they bargain in the shadow of the law. The legal rules governing alimony, child support, marital property, and custody give each parent certain claims based on what each would get if the case went to trial. In other words, the outcome that the law will impose if no agreement is reached gives each parent certain bargaining chips - an endowment of sorts. 


\section{Prepublication Draft: Marital Rights for Unmarried Partners?}

states, Minnesota and Texas, ${ }^{88}$ the partner insisting on it is likely to be the dominant one, not the subordinate one. ${ }^{89}$ The contract is more likely to take the form of what one lawyer calls a "Non-Marvinizing" agreement, under which the subordinate party purports to waive all rights. ${ }^{90}$ The subordinate party is likely just as hesitant to raise or press the subject of a contract as marriage. Subordinate parties who do press the issue, gently or not, are more likely to get vague oral statements than a written contract for their effort.

Consequently, the plaintiff in many litigated cases alleges an oral contract, which in the end may not be provable. The Marvin case fell

88 See Minn. Stat. ANN. $\S \S 513.075, .076$ (interpreted in Hollom v. Carey, 343 N.W.2d 701 (Minn. Ct. App. 1984)); TeX. Bus. \& Com. Code AnN. § 26.01(b)(3) (interpreted in Zaremba v. Cliburn, 949 S.W.2d 822 (Tex. Ct. App. 1997)).

89 The American Law Institute's PRINCIPLES OF THE LAW OF FAMILY DISSOLUTION: ANALYSIS AND RECOMMENDATIONS $\S \S 7.01(2)(a), 7.04(1)$ (2000) also require a written contract, but PRINCIPLES, unlike the law generally, provides that domestic partners as defined in $\S 6.03$ have marital-type rights upon dissolution of the relationship. See id. $\S \S 6.04$ to 6.06 .

Premarital and marital agreements must be in writing (see RESTATEMENT (ThiRd) OF Prop.: Wills AND OTHER DONATIVE TRANSFERS § 9.4 (2003); UNIF. Premarital AND Marital AgreEment ACt $\S 6$ (2012)), but the requirement is justified because married partners, unlike unmarried partners, have rights upon dissolution of the marriage.

${ }^{90}$ The lawyer, as reported in JANE BRYANT QUINN, MAKING THE MOST OF Your MONEY 84 (1991), is William P. Cantwell, who served as the Reporter for the UnIF. MARItal ProperTy ACt (1983). His "Non-Marvinizing" Agreement, which would be suitable for parties of equal bargaining power, states:

We have decided to live together beginning on . We do not intend that any common law marriage should arise from this. We have not made any promises to each other about economic matters. We do not intend any economic rights to arise from our relationship. If in the future we decide that any promises of an economic nature should exist between us, we will put them in writing, and only such written promises made by us in a written memorandum signed by us in the future shall have any force between us. Signed at on

Whether the law should treat a document such as this as effective is questionable without the safeguards of premarital agreements. See ALI PRINCIPLES, supra note 89 , at $\S 6.01(2)$ and $\mathrm{cmt} . b$. At a minimum, the law should require evidence of informed consent. See Restatement (Third) of Prop.: Wills and Other DONATIVE TRANSFERS $\S 9.4$ (2003); UNIF. PREMARITAL AND MARITAL AGREEMENT ACT $\S 9$ (2012). 


\section{Prepublication Draft: Marital Rights for Unmarried Partners?}

into this category. The plaintiff, Michelle Triola Marvin, ${ }^{91}$ brought a breach of contract action against the defendant, Lee Marvin. Because the trial court granted judgment on the pleadings for the defendant, the question on appeal was whether the plaintiff's complaint stated a cause of action. The California Supreme Court held that it did, but on remand Michelle could not prove her allegation.

The facts alleged in Michelle's complaint were that in October of 1964, she and Lee "entered into an oral agreement." As is typical of these complaints, Michelle not only listed the domestic services she agreed to perform but also the opportunities for employment or training she agreed to forgo. The services she listed were "companion, homemaker, housekeeper and cook." Michelle's forgone opportunities were "her lucrative career as an entertainer [and] singer." Lee, in turn, she alleged, not only agreed "to share equally any and all property accumulated" during the cohabitation ${ }^{92}$ but also "to provide for all of [her] financial support and needs for the rest of her life."

Michelle and Lee lived together for about five and a half years (from October 1964 through May 1970). ${ }^{93}$ During this period, she alleged, the parties as a result of their efforts and earnings acquired in Lee's name substantial real and personal property, including motion picture rights worth over \$1 million. In May 1970, however, Lee (in the language of the complaint) "compelled" her to leave his household. He continued to support her for another year and a half (until November 1971), but thereafter refused to provide further support.

${ }^{91}$ Michelle Triola officially changed her surname to Marvin, even though she and Lee Marvin never married.

92 Michelle's actual allegation was that the parties agreed that "they would combine their efforts and earnings and would share equally any and all property accumulated as a result of their efforts whether individual or combined." But, since it appears that the parties contemplated that Michelle would remove herself from the work force, it appears that it was Lee's earnings that were to be shared.

93 According to her Wikipedia entry, available at https://en.wikipedia.org/wiki/Michelle_Triola_Marvin, Michelle Triola began living in Malibu with the actor Dick Van Dyke in 1976. She lived with Van Dyke until her death in 2009 at age 76. They never married. Van Dyke is still living, but Lee Marvin died at age 63 in 1987. 


\section{Prepublication Draft: Marital Rights for Unmarried Partners?}

In a landmark decision, the California Supreme Court held that her complaint stated a cause of action. The Marvin decision addressed two questions. First, is an express contract enforceable, assuming that it can be proved if oral? Second, if no express contract can be proved, does the disappointed cohabiting partner have any rights at all?

The principal obstacle to recovering for breach of an express oral contract, other than the necessity of proving the contract, was what the courts call the "meretricious" nature of such a relationship - that the relationship involved sexual activity. Because prostitution is illegal, ${ }^{94}$ a contract for prostitution is unenforceable. ${ }^{95} \mathrm{~A}$ few postMarvin decisions in other states - Georgia and Illinois - have held that contracts between unmarried cohabitors are unenforceable for that reason alone, citing public policy grounds. ${ }^{96}$ Those decisions are still presumptively good law in those states.

The Marvin court sought to remove the meretriciousconsideration obstacle to enforcement. The court held that the sexual component of the arrangement could prevent enforcement only if the contract was "expressly and inseparably based upon an illicit consideration of sexual services." 97 This was not the case in Marvin, for Michelle did not allege that one of the services for which Lee agreed to pay was for her to be his lover.

94 See, e.g., CAL. PENAL CODE $\S \S 653.20$ to 653.28 . For a link to prostitution laws in all states, see FindLaw.com, State Prostitution Laws, available at http://statelaws.findlaw.com/criminal-laws/prostitution.html.

95 See, e.g., CAL. CIV. CODE $§ \S 1596,1598$.

${ }^{96}$ See, e.g., Rehak v. Mathis, 238 S.E.2d 81 (Ga. 1977) ("It is well settled that neither a court of law nor a court of equity will lend its aid to either party to a contract founded upon an illegal or immoral consideration. Code Ann. § 20-501.... The parties being unmarried and the appellant having admitted the fact of cohabitation in both verified pleadings, this would constitute immoral consideration under Code Ann. § 20-501 ...”.); Hewitt v. Hewitt, 394 N.E.2d 1204 (Ill. 1979) ("Illinois' public policy regarding agreements such as the one alleged here was implemented long ago ...where this court said: 'An agreement in consideration of future illicit cohabitation between the plaintiffs is void.' ... The issue, realistically, is whether it is appropriate for this court to grant a legal status to a private arrangement substituting for the institution of marriage sanctioned by the State. The question whether change is needed in the law... [is best left to] the legislative branch ...")

${ }^{97}$ Marvin, 557 P.2d at 114. 


\section{Prepublication Draft: Marital Rights for Unmarried Partners?}

The time has surely come to put the meretricious-consideration argument behind us. It is surely time to remove it as an obstacle to enforcement of these agreements, as the Supreme Court of Connecticut held in Boland v. Catalano, ${ }^{98}$ for there is no way these cases involve agreements for prostitution. Perhaps the Marvin court thought it had done that by making contracts enforceable unless the contract was "expressly and inseparably" based upon "sexual services." In adopting this as a determining principle, the court may have been groping for a way to fit domestic partnerships into a spectrum between contracts for prostitution on the one end and marriages on the other. Marriages, like cohabiting partnerships, undeniably involve both a financial and a sexual component. But so do contracts for prostitution. Perhaps the Marvin court thought that the distinction between marriage and prostitution was that the sexual and financial components are express and inseparable in the case of prostitution, whereas in marriage, the two components are not expressly dependent upon each other. The existence of these two components in a marriage is merely inherent in the nature of the marital relationship. Perhaps the Marvin court concluded that a good way to liken cohabiting partnerships to marriages and not to contracts for prostitution was to emphasize the express and inseparable interdependence of the financial and sexual components in a contract for prostitution.

A truer distinction between marriage and the typical contract for prostitution is the existence in marriage of the linking together of two whole lives, emotionally, financially, and physically, through sharing the same household in an arrangement involving love, romance, commitment, caring, and so on. This third component is missing from a typical contract for prostitution, but it is not missing from a cohabiting partnership. The Marvin court would have been on sounder ground if it had distinguished contracts for prostitution from cohabiting partnerships on this basis rather than on the "express and inseparable" basis. This approach would have completely removed

98521 A.2d 142, 146 (Conn. 1987) ("We conclude that our public policy does not prevent the enforcement of agreements regarding property rights between unmarried cohabitants in a sexual relationship.") 
Prepublication Draft: Marital Rights for Unmarried Partners?

the obstacle of meretricious consideration from enforcement of the financial component of cohabiting-partnership contracts.

Perhaps the Marvin court thought that the "express and inseparable" distinction itself eliminated the meretricious consideration obstacle for all cohabiting partnership cases. If so, it did not turn out that way. It was easy in Marvin to sever the sexual component of the parties' relationship, because Michelle's complaint never alleged that one of her "services" was to be Lee's lover. Nevertheless, in a subsequent California case, Jones v. Daly, ${ }^{99}$ the plaintiff made the mistake of alleging in his complaint that one of the services he agreed to perform, in addition to domestic services, was to be the defendant's "lover." This proved to be fatal, for the court held that the complaint did not state a cause of action, citing the ground that the plaintiff's "allegations clearly show that plaintiff's rendition of sexual services to Daly was an inseparable part of the consideration for the 'cohabitors agreement,' and indeed was the predominant consideration." "There is," the court said, "no severable portion of the "cohabitors agreement' supported by independent consideration." 100

The solution came in a still later case, Whorton v. Dillingham. ${ }^{101}$ The complaint in that case listed mutual sexual promises - that the plaintiff promised to be the defendant's "lover" and that the defendant promised to be the plaintiff's "lover." The court held the complaint stated a cause of action. In a key passage, the court stated that "by itemizing the mutual promises to engage in sexual activity, [the plaintiff] has not precluded the trier of fact from finding those promises are the consideration for each other and independent of the bargained for consideration for [the plaintiff's] employment." ${ }^{102}$

The Whorton analysis suggests a responsible way around the problem in a jurisdiction forced to work within the "express and inseparable" distinction. Even if sexual intimacy is listed in the complaint on only one side, surely the way to handle these cases is to

\footnotetext{
99176 Cal. Rptr. 130 (Cal. Ct. App. 1981).

${ }^{100} \mathrm{Id}$ at 134.

${ }^{101} 248$ Cal. Rptr. 405 (Cal. Ct. App. 1988).

${ }^{102}$ Id. at 409-10.
} 


\section{Prepublication Draft: Marital Rights for Unmarried Partners?}

presume that the sexual component of a cohabitation is always separable from the other parts of the contract, on the ground - to be blunt - that the consideration for sex is sex. I do not want to be understood as saying that the idea that the consideration for sex is sex is a realistic way of analyzing the complicated emotional, financial, and physical relationships that exist in a cohabiting partnership, anymore than I would suggest that this idea is a realistic way of analyzing those relationships in a marriage. My point is merely that, in a jurisdiction forced to work under the "express and inseparable" principle, this is a convenient, though fictitious, way of dealing with the problem.

\section{B. Recovery Based on Status}

\section{Common-Law Marriage}

Most states have abolished common-law marriage by statute. ${ }^{103}$ Only ten states and the District of Columbia still recognize the concept. The ten states are Alabama, Colorado, Iowa, Kansas, Montana, Oklahoma, ${ }^{104}$ Rhode Island, South Carolina, Texas, and Utah. ${ }^{105}$ New Hampshire recognizes common-law marriage, but only for purposes of intestacy. ${ }^{106}$ After Obergefell, ${ }^{107}$ common-law marriages in these states would be open to same sex couples.

The general elements of common-law marriage are capacity to enter into a marriage (for example, not being married to someone

103 See, e.g., Mich. COMP. LAWs ANN. § 551.2. See also UNMARRIED EQUALITY, Common law Marriage Fact Sheet, available at http://www.unmarried.org/common-law-marriage-fact-sheet/; NAT'LCONFERENCE OF State Legislatures, Common law Marriage by State, available at http://www.ncsl.org/research/human-services/common-law-marriage.aspx.

${ }^{104}$ There is some uncertainty in Oklahoma. See Common-law Marriage Fact Sheet, supra note 103.

105 Common-law marriages are recognized in the following states only if created before a certain date: Georgia if created before Jan. 1, 1997 (GA. CODE ANN. § 19-3.1.1), Idaho if created before Jan. 1, 1996 (IDAHO CODE § 32-201), Ohio if created before Oct. 19, 1991 (OHIO REV. CODE ANN. § 3105.12(B)), and Pennsylvania if created before Jan. 1, 2005 (23 PA. CONS. STAT. § 1103).

106 "Persons cohabiting and acknowledging each other as husband and wife, and generally reputed to be such, for the period of 3 years, and until the decease of one of them, shall thereafter be deemed to have been legally married." N.H. REV. STAT. ANN. § 457.39.

${ }^{107}$ Obergefell, 576 U.S.___ (June 26, 2015), Slip Opinion No. 14-556. 


\section{Prepublication Draft: Marital Rights for Unmarried Partners?}

else), a present agreement to be married (not an agreement to get married in the future), cohabitation (but no period of cohabitation is necessary), and holding out as married to the community. ${ }^{108}$ Negative judicial and legislative reaction to the concept of common-law marriage grew during the late nineteenth century. One criticism of the concept was that the informality of common-law marriages makes them highly vulnerable to fraud and perjury. More prominent was the argument that recognition of common-law marriage undermines formal marriage. ${ }^{109}$ One commentator who has studied common-law marriage has concluded that the fear of fraud does not stand up to scrutiny and that other objections are outweighed by more important values, such as the protection of women, especially poor women. ${ }^{110}$

There is no proof that recognition of common-law marriage undermines formal marriage: Despite the legal and other advantages of formal marriage, ${ }^{111}$ formal marriage is already on the decline and unmarried cohabitation is on the rise irrespective of whether a state recognizes or has abolished common-law marriage. The 2010 Census Bureau Report on Households and Families ${ }^{12}$ lists - for the whole country and jurisdiction-by-jurisdiction - the percentage of unmarried opposite-sex partner households and husband-and-wife households. The following table shows the results for the country and for the jurisdictions that recognize common-law marriage. Because each household self-reports its own identity, the husband-and-wife listings do not distinguish between formal-marriage households and commonlaw marriage households. If they did, we would know for sure whether there are below average formal marriages in common-law marriage jurisdictions and enough common-law marriages to bring the total roughly up to par. Nevertheless, we can get some clue by comparing husband-and-wife households with unmarried opposite-

\footnotetext{
108 See Cynthia Grant Bowman, A Feminist Proposal to Bring Back Common Law Marriage, 75 OR. L. REV. 709, 712-15 (1996).

109 See, e.g., Sorenson v. Sorenson, 100 N.W. 930, 932 (Neb. 1904). See generally MichaEL GROSSBERG, GOVERNING THE HEARTH: LAW AND THE FAMILY IN NINETEENTH-CENTURY AMERICA (1985).

110 See Bowman, supra note 108, at 779-80.

111 See supra text accompanying notes 39-49.

112 U.S. Census Bureau, Households and Families: 2010 (April 2012), available at http://www.census.gov/prod/cen2010/briefs/c2010br-14.pdf.
} 


\section{Prepublication Draft: Marital Rights for Unmarried Partners?}

sex partner households, on the theory that in common-law marriage jurisdictions, some couples who had not formally married would identify their relationship as husband and wife rather than unmarried. If so, the results should show a consistent pattern in which the percentage of self-reported husband-and-wife households is above average and the percentage of unmarried opposite-sex partner households is below average. The results show no such consistent pattern. Five of the eleven common-law marriage jurisdictions - Colorado, Kansas, Oklahoma, Texas, and Utah-fit that pattern but the other six-Alabama, the District of Columbia, Iowa, Montana, Rhode Island, and South Dakota - do not. Of the five, Utah is the only jurisdiction that shows a dramatic difference in result. But the comparative results for one idiosyncratic jurisdiction fall far short of proving that common-law marriage discourages formal marriage. While recognition of common-law marriage may play a part in Utah, other cultural differences probably play a part as well. ${ }^{113}$ Overall, there is no consistent pattern showing that recognition of common-law marriage undermines formal marriage. Quite the opposite: The results are inconsistent with that proposition.

${ }^{113}$ Professor Bowman, supra note 108, at 749-50, explains that the Utah statute recognizing common-law marriage, which was enacted in 1987, may have been based on the false premise that it was necessary to prevent couples from excluding one person's income when applying for Aid to Families with Dependent Children. 
Prepublication Draft: Marital Rights for Unmarried Partners?

Table 3

Unmarried Opposite-Sex Partner and Husband-Wife

Households: 2010

\begin{tabular}{|l|c|c|}
\hline $\begin{array}{c}\text { United States } \\
\text { and Individual } \\
\text { Jurisdictions } \\
\text { Recognizing Common- } \\
\text { law Marriage }\end{array}$ & $\begin{array}{c}\text { Opposite Sex } \\
\text { Unmarried Partner } \\
\text { Households as } \\
\text { Percentage of All } \\
\text { Households in that } \\
\text { Jurisdiction }\end{array}$ & $\begin{array}{c}\text { Self-identified } \\
\text { Husband-Wife } \\
\text { Households as a } \\
\text { Percentage of All } \\
\text { Households in that } \\
\text { Jurisdiction }{ }^{\text {115 }}\end{array}$ \\
\hline United States & $\mathbf{5 . 9}$ & $\mathbf{4 8 . 4}$ \\
\hline Alabama & 4.1 & 47.9 \\
\hline Colorado & 5.6 & 49.2 \\
\hline District of Columbia & 5.8 & 22.0 \\
\hline Iowa & 6.2 & 51.2 \\
\hline Kansas & 5.3 & 51.1 \\
\hline Montana & 6.1 & 49.2 \\
\hline Oklahoma & 5.3 & 49.5 \\
\hline Rhode Island & 6.7 & 44.5 \\
\hline South Dakota & 6.1 & 50.1 \\
\hline Texas & 5.2 & 50.6 \\
\hline Utah & 3.9 & 61.0 \\
\hline
\end{tabular}

In some states where common-law marriage has been abolished, courts have applied a de facto common-law marriage doctrine to couples who lived together in a common-law marriage state. In Kellard v. Kellard, ${ }^{116}$ a New York man and woman, unmarried but

\footnotetext{
${ }^{114}$ Id. tbl. 6, at 16.

${ }^{115} I d$. tbl. 4, at 10 .

11613 FAM. L. REP. (BNA) 1490 (N.Y. Sup. Ct. 1987).
} 
Prepublication Draft: Marital Rights for Unmarried Partners?

cohabiting with one another, took an automobile trip to Disney World in 1978. During the trip, they stayed overnight in a motel in South Carolina where they registered as husband and wife, and engaged in sexual intercourse. They also stayed for two nights in a motel in Georgia. Some years later, in defense to a divorce suit filed in New York by the woman, the man claimed that no divorce was necessary because he was not married to the plaintiff. A New York court rejected his defense, holding that the couple's behavior en route to Disney World satisfied the common-law marriage requirements of South Carolina and Georgia. This, along with the lengthy history of the couple's relationship, led the court to recognize them as married. ${ }^{117}$

\section{In States That Have Abolished Common-Law Marriage}

What if an unmarried cohabitor enters upon a cohabitation arrangement without contractual protection in a state that has abolished common-law marriage? In Marvin, Michelle Triola alleged an oral contract, but a plaintiff who alleges an oral contract has the burden of proof and she was unable to carry that burden. The courts in a few jurisdictions have closed the door to plaintiffs without an express contract ${ }^{118}$ and at least two state legislatures, Minnesota and

\footnotetext{
117 See also Gary Taylor, Increased Mobility Adds to Common Law Claims, NAT'L L.J., Aug. 14, 1989, at 24.

${ }^{118}$ See, e.g., Levar v. Elkins, 604 P.2d 602 (Alaska 1980); Boland v. Catalano, 521 A.2d 142 (Conn. 1987); Aehegma v. Aehegma, 797 P.2d 74 (Haw. Ct. App. 1990); Estate of Alexander, 445 S.2d 836 (Miss. 1984); Dominguez v. Cruz, 617 P.2d 1322 (N.M. Ct. App. 1980); Morone v. Morone, 413 N.E.2d 1154 (N.Y. 1980). The Alexander court held that if a remedy is to be given to a surviving cohabitant in the absence of an express contract, "the Legislature should provide the remedy." See also Carries v. Sheldon, 311 N.W.2d 747 (Mich. Ct. App. 1981) (although prior Michigan cases have held that express contracts are enforceable to the extent they are based on independent consideration, and have enforced contracts implied in fact for wages or for the value of commercial services, the court in the instant case was "unwilling to extend equitable principles to the extent plaintiff would have us do, since recovery based on principles of contracts implied in law essentially would resurrect the old common-law marriage doctrine which was
} 


\section{Prepublication Draft: Marital Rights for Unmarried Partners?}

Texas, have closed the door to plaintiffs without an express written contract. ${ }^{119}$ The advantage of such a bright-line test, especially the one that insists on an express written contract, is that it introduces an element of efficiency into the law in the manner of the Statute of Frauds and similar to the efficiency accruing from grounding spousal rights on status. The cohabiting partner with a contract can claim the contractual rights without having to prove anything about the underlying details or commitment of the relationship. Just as the marriage certificate qualifies the spouse for what the law allows, the written contract qualifies the cohabiting partner-plaintiff for what the contract allows.

The disadvantage is that plaintiffs with just claims are shut out. This category includes plaintiffs who are in a "subordinate" position to the defendant in terms of bargaining power, and hence are unable to obtain contractual protection. ${ }^{120}$ More importantly, perhaps, this category also includes a disproportionate number of plaintiffs who are unsophisticated in the ways of the law.

To its credit, the court in the Marvin case thought that there would be cases that warranted relief even without a contract, and there are cases in which the plaintiff's claim seems undeniably just. In seeking to find a way of analyzing this problem, the court in Marvin used an interesting phrase. The court spoke, and spoke repeatedly, of enforcing the "reasonable expectations of the parties." "The courts may inquire into the conduct of the parties ${ }^{121}$ to determine whether

specifically abolished by the Legislature.... [J]udicial restraint requires that the Legislature, rather than the judiciary, is the appropriate forum for addressing the question raised by plaintiff. We believe a contrary ruling would contravene the public policy of this state 'disfavoring the grant of mutually enforceable property rights to knowingly unmarried cohabitants."').

${ }^{119}$ See supra note 88.

${ }^{120}$ See supra notes $87-90$ and accompanying text.

${ }^{121}$ According to Professor Glendon, the reference to an inquiry into the conduct of the parties raised "the prospect of litigation in which the private lives of the parties can be explored in detail [and] has led already to the settlement out of court of a number of suits by alleged same-sex lovers or clandestine playmates of well- 
Prepublication Draft: Marital Rights for Unmarried Partners?

that conduct demonstrates an implied contract or implied agreement of partnership or joint venture, or some other tacit understanding between the parties," the court said.

In speaking of the "reasonable expectations of the parties"-plural - the court was probably knowingly engaging in a fiction. Few could doubt that the parties in the Marvin case did not enter or continue the arrangement with the same expectations. Some interesting empirical research has shown that different expectations are standard. The study found:

In 39 percent of the cases for which we have couple data, one party believes they will marry and the other does not! This difference of perception is surely a factor in the higher instability of these unions. Another 11 percent agree that they will not get married, making just about half of all cohabiting couples where there is disagreement about marriage or no plans to marry. Twenty-nine percent agree that they have definite plans to marry, and in another 20 percent of the cases one partner has definite plans to marry, while the other thinks they will marry but does not have definite plans to do so. ${ }^{122}$

known people." See MARY ANN GLENDON, THE TRANSFORMATION OF FAMILY LAW 279 (1989).

${ }^{122}$ Larry L. Bumpass et al., supra note 63, at 14. See also Ronald R. Rindfuss \& Audrey VandeHenvel, Cohabitation: Precursor to Marriage or an Alternative to Being Single, 16 Population \& DeV. ReV. 703, 721 (1990) (empirical study finding that "cohabitors are substantially more similar [in their attitudes toward matters such as marriage and childbearing plans] to the singles than to the married"). A later study, however, found "a fairly high level of consensus" about marriage plans among heterosexual cohabitors who were age 35 and younger:

Seventy percent of those who report that they have definite plans to marry their partner live with a partner who reports that they have definite plans to marry them. An additional 14 percent had partners who thought that they would marry them. Only about 6 percent had partners who did not expect to marry them or who did not know whether or not they would marry.

James A. Sweet \& Larry L. Bumpass, Young Adults' View of Marriage, 
Prepublication Draft: Marital Rights for Unmarried Partners?

To be sure, this study reports on marriage expectations in shorterterm cohabitations, and the Marvin court's emphasis was on a different type of expectation - the expectation that there will be "profit-sharing." To be sure, also, the emphasis here is on the longerterm cohabitations, those that are the exception overall but tend to accumulate in the population. In any event, Lee Marvin and Michelle Triola, it would probably be safe to speculate, did not share the same expectations, not even when entering into or during the happy periods of their arrangement. Michelle probably hoped and maybe even expected that Lee would eventually marry her or, failing that, that he would "do right" by her financially. Whether Lee ever intended to do either is unclear. He certainly determined never to give her a dime shortly after they broke up.

So, what do we make of the court's emphasis on "the reasonable expectations of the parties"? The court could be saying one of two things. One is that there should be an inquiry into whether the defendant's behavior reasonably led the plaintiff to think that he had the same expectations she did, i.e., whether the defendant led her on. The other, more significant possibility is that the court is saying that it will attribute or impute "reasonable" expectations even when they are fictional regarding one of them.

Although this latter idea came to nothing in the Marvin case itself, ${ }^{123}$ some courts, in later cases, have applied this idea. Case authority has held that committed cohabitation relationships have the

Cohabitation, and Family, Working Paper No. 33, at 5 (Nat'1 Survey of Families and Households, 1990).

${ }^{123}$ On remand, Michelle failed to prove the existence of an express or implied contract, but the trial court awarded her $\$ 104,000$ for rehabilitation on the ground of an unspecified equitable theory. On appeal, the judgment granting this award was reversed for want of a "recognized underlying obligation in law or in equity." Marvin v. Marvin, 176 Cal. Rptr. 555 (1981). See also Taylor v. Polackwich, 194 Cal. Rptr. 8 (1983) ("rehabilitative award" reversed on appeal). 


\section{Prepublication Draft: Marital Rights for Unmarried Partners?}

same force and effect as a legal marriage. ${ }^{124}$ Many if not all of these cases involve relationships that would be common-law marriages but for the abolition of that doctrine. Two examples will suffice. ${ }^{125}$ The first is Goode v. Goode, ${ }^{126}$ a West Virginia case. Carl and Martha Goode separated after having lived together for twenty-eight years. Although the couple had never formally married, they had consistently held themselves out to the public as husband and wife. They had four children. Martha, age 47, filed a divorce action against Carl, age 61, seeking an equitable division of the property they had acquired during their 28-year period of cohabitation. Although West Virginia is not a common-law marriage state, the court held that Martha could recover, saying:

[W] hold that a court may order a division of property acquired by a man and woman who are unmarried cohabitants, but who have considered themselves and held themselves out to be husband and wife. Such order may be based upon principles of contract, either express or implied, or upon a constructive trust. Factors to be considered in ordering such a division of property may include: the purpose, duration, and stability of the relationship and the expectations of the parties. Provided, however, that if either the man or woman is validly married to another person during the period of cohabitation, the property rights of the spouse and

\footnotetext{
${ }^{124}$ For examples of cases providing for equitable division of property acquired while the couple cohabited before marrying or acquired while the couple cohabited after having divorced each other, see Eaton v. Johnson, 10 Fam. L. Rep. (BNA) 1094 (Kan. Ct. App. 1983); Pickens v. Pickens, 490 So.2d 872 (Miss. 1986); Connell v. Francisco, 898 P.2d 831 (Wash. 1995) (applying the principle of Marriage of Lindsey, 678 P.2d 328 (Wash. 1984)).

${ }^{125}$ Other post-Marvin cases have asserted claims based on nonfamily doctrines, such as express contract, contract implied in fact, contract implied in law, quantum meruit, and constructive trust. See, e.g., Bright v. Kuehl, 650 N.E.2d 311 (Ind. Ct. App. 1995); Western States Construction, Inc. v. Michoff, 840 P.2d 1220 (Nev. 1992); Watts v. Watts, 405 N.W.2d 303 (Wis. 1987). Decisions in many of these cases are ambiguous as to whether the court based recovery on a contract implied in fact or on unjust enrichment grounds.

${ }^{126} 396$ S.E.2d 430 (W. Va. 1990).
} 


\section{Prepublication Draft: Marital Rights for Unmarried Partners?}

support rights of the children of such man or woman shall not in any way be adversely affected by such division of property. ${ }^{127}$ The expectations of the parties under these circumstances would be equitable treatment by the other party in exchange for engaging in such a cohabiting relationship.

My second example is a case that goes even farther and allows an unmarried plaintiff to utilize the divorce laws directly. That case is Warden v. Warden. ${ }^{128}$ Charles Warden and Denise Boursier began living together in 1963, holding themselves out as husband and wife. They had two children. In 1972, Charles moved to California and formally married another woman. After learning of this, Denise brought suit under the divorce laws for child support and an equitable division of property, which the trial court awarded. Charles appealed that part of the judgment decreeing a division of the property. Although Washington is not a common-law marriage state, the Washington Court of Appeals affirmed, saying:

We believe the time has come for the provision of [the Washington statute providing for equitable division of property upon dissolution of a marriage] to govern the disposition of the property acquired by a man and a woman who have lived together and established a relationship which is tantamount to a marital family except for a legal marriage.

\footnotetext{
${ }^{127}$ Under the facts of this case, the parties lived together for an extended period of time, considered themselves as husband and wife, and, in fact, pooled their resources to include taking property under three joint deeds. Therefore, in this case, the equities are more easily determined than in a relationship between two parties which was for a shorter duration, or where the parties did not consider themselves to be husband and wife, or where the parties did not pool their resources. Cases in other jurisdictions have noted that "[e]ach case should be assessed on its own merits with consideration given to the purpose, duration and stability of the relationship and the expectations of the parties." Hay v. Hay, 678 P.2d 672, 674 (1984). [Footnote by the court.]

128676 P.2d 1037 (Wash. Ct. App. 1984). See also Western States Construction, Inc. v. Michoff, 840 P.2d 1220 (Nev. 1992).
} 
Prepublication Draft: Marital Rights for Unmarried Partners?

The trial judge here properly treated Denise and Charles as a marital family and correctly considered the length and purpose of their relationship, the two children, the contributions of the parties, and the future prospects of each. He correctly assumed that both Denise and Charles contributed to the acquisition of the property and divided it in a manner which was "just and equitable after considering all relevant factors." 129

Once the case law grants extra-contractual rights to disappointed cohabiting partners, the law is granting rights based on "status." Unlike marital status, though, each litigated cohabitation must be probed in order to classify the relationship as a marriage in fact or not as a marriage in fact to determine whether relief is warranted. Each plaintiff must prove that the underlying nature of his or her relationship with the defendant warrants recovery. The extract quoted from the Warden opinion gives some idea of what must be proved. Another definition comes from the New York case of Braschi v. Stahl Associates Co., ${ }^{130}$ a case that involved an analogous question under the New York rent control laws: There must be, the court said:

an objective examination of the relationship of the parties[, including] the exclusivity and longevity of the relationship, the level of emotional and financial commitment, the manner in which the parties have conducted their everyday lives and held themselves out to society, and the reliance placed upon one another for daily family services.... These factors are most helpful, although it should be emphasized that the presence or absence of one or more of them is not dispositive since it is the totality of the relationship as evidenced by the dedication, caring and self-

129 Id. at 1039-40. Contra, Crowe v. De Gioia, 495 A.2d 889, 897-98 (N.J. Super. Ct. App. Div. 1985), aff'd, 505 A.2d 591 (N.J. 1986) (rejecting plaintiff's claim for equitable distribution of defendant's property).

${ }^{130}$ 139. 543 N.E.2d 49 (N.Y. 1989). 


\section{Prepublication Draft: Marital Rights for Unmarried Partners?}

sacrifice of the parties which should, in the final analysis, control. ${ }^{131}$

\section{A Uniform De Facto Marriage Act?}

Now that same-sex marriage is legal in all American jurisdictions, many same-sex couples who were previously cohabiting will enter into a formal marriage. But some will continue to cohabit without doing so, just as many opposite-sex couples continue to cohabit without doing so. The time may now be ripe to start thinking about the rights, if any, of unmarried cohabitors. I addressed this matter long ago, in my Joseph Trachtman Lecture at the 1992 annual meeting of the American College of Trust and Estate Counsel. ${ }^{132}$ Other scholars have more recently raised the matter. ${ }^{133}$

The questions the case law described in Part II leaves us with are these: Can — and should — we replace the case-by-case, hit-or-miss adjudication with legislation — a De Facto Marriage Act — that adopts criteria for determining which cohabiting couples have martial rights and which do not?

131 Id at 55. See also Mary Patricia Truethart, Adopting a More Realistic Definition of “Family," 26 GonZAGA L. REV. 91 (1990/91).

${ }^{132}$ See Lawrence W. Waggoner, Marital Property Rights in Transition, 18 THE Probate LAWYER 1, 47-66 (1992).

133 See Huntington, supra note 63; Scott \& Scott, supra note 63, at 18-19 (arguing that "The fact that the law confers deference and societal resources on marriage does not mean that the privileged status of this traditional family form should be exclusive" and noting that "legal benefits are sometimes extended to adult de facto relationships on the basis of their similarity to marriage," and, at 65, that "[s]ome cohabiting couples are clearly in family relationships, and regulators may be able to employ a few straightforward proxies to minimize verifiability problems.”); Douglas NeJaime, Marriage Equality and the New Parenthood, 129 HARV. L. REV. __ _ (forthcoming 2016); Anna Stępień-Sporek \& Margaret Ryznar, The Consequences of Non-Marriages, 49 U.S.F. L. REV.page proofs at 1425 (forthcoming 2015) (canvassing legal treatment of cohabiting couples in Europe), available at http://ssrn.com/abstract=2603990; Deborah A. Widiss, NonMarital Families and (or After?) Marriage Equality, 42 FLA. ST. U. L. REV. 547 (2015). 


\section{Prepublication Draft: Marital Rights for Unmarried Partners?}

My principal purpose here is, first, to draw attention to the problem and secondly, to draw attention to the fact that other Englishspeaking jurisdictions have enacted or introduced legislation granting marital rights to cohabiting couples if their relationship meets specific criteria. Legislation recognizing marital rights has been enacted or introduced in Australia, ${ }^{134}$ Canada, ${ }^{135}$ New Zealand, ${ }^{136}$ and the United Kingdom. $^{137}$

In this country, the American Law Institute (ALI) has recognized that longer-term cohabitants have rights similar to married couples upon dissolution of the relationship. ${ }^{138}$ Because the ALI put forward its project as what it calls "Principles of the Law," which the ALI says are "primarily addressed to legislatures," 139 I refer to that project as the "ALI Unmarried Partner Statute." The ALI, however, is known for its Restatements of the Law, which are directed to courts, not legislatures. ${ }^{140}$ Although the ALI Unmarried Partner Statute has not been transformed into a bill and introduced in any state legislature, the explanation may lie elsewhere than on the merits of the proposal. The ALI is not organized to take any post-publication action to

134 Australia Family Law Act 1975 § 4AA; New South Wales Property (Relationships) Act 1984 § 4; Northern Territory De Facto Relationships Act 1991 $\S \S 3 \mathrm{~A}, 10,24,28,52$; Queensland Acts Interpretation Act $1954 \S 32 \mathrm{DA}$; Queensland Commonwealth Powers (De Facto Relationships) Act 2003; Queensland Succession Act $1981 \S 5$ AA.

${ }^{135}$ Alberta Adult Interdependent Relationships Act, SA 2002, c. A-4.5, § 3(1); British Columbia Family Law Act $\S 3$; Ontario Family Law Act $\S 29$.

${ }^{136}$ New Zealand Property (Relationships) Act 1976 § 2A - 2E.

137 UK Cohabitation Rights Bill [H.L. Bill 29] 2015-16 ( $1^{\text {st }}$ reading 4 June 2015); UK Law Comm. Rep. No. 331, 13 Dec. 2011 (Draft Inheritance (Cohabitants)) Bill (13 Dec. 2011).

138 PRINCIPLES OF THE LAW OF FAMILY DiSSOLUTION: ANALYSIS AND RECOMMENDATIONS $\S \S 6.01$ to 6.06, app. II, $\S 5.09$ (2000) [hereinafter ALI UNMARRIED PARTNER STATUTE].

139 See ALI, How Do Principles of the Law Differ from Restatements of the

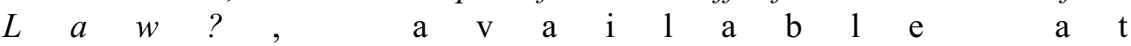
https://www.ali.org/publications/frequently-asked-questions/\#differ.

${ }^{140}$ Full disclosure: I have been a Restatement Reporter: Restatement (Third) of Property: Wills and Other Donative Transfers (1999, 2003, 2011). 


\section{Prepublication Draft: Marital Rights for Unmarried Partners?}

promote enactment of its Principles Statutes. Moreover, the sections dealing with unmarried partners is a small part of a much larger project dealing principally with dissolution of formal marriages - allocation of custodial and decisionmaking responsibility for children, child support, division of property upon dissolution, compensatory spousal payments, and premarital, marital, and separation agreements.

The Uniform Law Commission (ULC) is the law-reform organization whose sole purpose is drafting and promoting its legislation. That makes the ULC the logical organization for studying the problem of marital rights for cohabiting couples. ${ }^{141}$ The question for study is whether a De Facto Marriage Act could and should be enacted here. ${ }^{142}$ In studying the problem, the ULC will find helpful the Commonwealth, ALI, and other sources. ${ }^{143}$

\footnotetext{
${ }^{141}$ Full disclosure: I have drafted legislation for the ULC and have been Chief Reporter and Director of Research for the Joint Editorial Board for Uniform Trust and Estate Acts. I served as Reporter for the Uniform Probate Code Article II Revisions (promulgated 1990, 1993, 2008, and 2009), the Revised Uniform Testamentary Additions to Trusts Act (promulgated 1991), the Revised Uniform Simultaneous Death Act (promulgated 1991), and the Uniform Statutory Rule Against Perpetuities (promulgated 1986).

${ }^{142}$ See Uniform Law Commission, Statement of Policy Establishing Criteria and Procedures for Designation and Consideration of Uniform and Model Acts, $\begin{array}{lllllllllll}\mathrm{a} & \mathrm{v} & \mathrm{a} & \mathrm{i} & \mathrm{l} & \mathrm{a} & \mathrm{b} & 1 & \mathrm{e} & \mathrm{a} & \mathrm{t}\end{array}$ http://www.uniformlaws.org/Narrative.aspx?title=Criteria\%20for $\% 20 \mathrm{New} \% 20 \mathrm{P}$ rojects.

${ }^{143}$ In addition to the UK and Commonwealth statutes and the ALI Unmarried Partner Statute, there are numerous Law Revision Commission Reports that support the idea of de facto marriage. See, e.g., UK Law Comm'n Consultation Paper No.

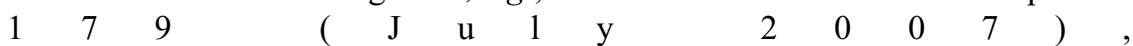
http://www.lawcom.gov.uk/wp-content/uploads/2015/03/cp179_Cohabitation_C onsultation.pdf; UK Law Comm'n, Intestacy and Family Provision Claims on Death, Rep. No. 331, I 1.99 at 24 (Dec. 2011), http://www.lawcom.gov.uk/wp-content/uploads/2015/03/lc331_intestacy_report. pdf; Queensland Law Reform Comm'n, De Facto Relationships, Rep. No. 44 (June 1993); Queensland Law Reform Comm'n, Intestacy Rules, Rep. No. 42 (June $1 \quad 9 \quad 9 \quad 3 \quad$ ) , http://www.lawcom.gov.uk/wp-content/uploads/2015/03/lc331_intestacy_report.
} 


\section{Prepublication Draft: Marital Rights for Unmarried Partners?}

A De Facto Marriage Act would codify the principle that unmarried partners can gain marital rights and would codify the criteria for qualifying for such rights. In the case of married partners, the marriage license, the wedding ceremony, and the marriage certificate signify intent to acquire the rights of marriage. More accurately, the marriage laws attribute that intent to married partners, because it is unlikely that many married partners actually formed that intent with full knowledge of what those rights are. Cohabiting couples have none of these official indicia of intent. On what basis, then, should the law ever declare that cohabiting couples have become married in fact, i.e., have a de facto marriage? For them, a De Facto Marriage Act would treat committed behavior occurring over time as signifying (again, by attribution) intent to acquire the rights of formal marriage. If a relationship that has been edging toward de facto marriage continues to progress along that continuum, the relationship will likely, at some point, cross the line between cohabitation and marriage in fact. That would be the tipping point - the time when a court of competent jurisdiction could justifiably declare the couple's relationship as having reached marital status.

How should a De Facto Marriage Act be crafted? On this, the Commonwealth statutes and other resources have reached a general consensus. The Act would codify an overriding standard for determining whether a de facto marriage has occurred and then list factors for a court to take into account in determining whether that standard has been satisfied.

The starting point is that the couple must not be married to anyone else $^{144}$ and must not be prohibited from marrying one another. Although some of the Commonwealth statutory standards are more detailed than others, and different statutes formulate the standard

pdf.

${ }^{144}$ The ALI Unmarried Partner Statute departs from this requirement. See ALI UNMARRIED PARTNER STATUTE, supra note 138, at $§$ 6.01(5) \& cmt. $c$. 


\section{Prepublication Draft: Marital Rights for Unmarried Partners?}

differently, they are all aiming at the same general requirement: the partner's behavior must demonstrate enough of a commitment toward one another to justify declaring that they are married in fact. Some of the Commonwealth statutes use the term "marriage-like." ${ }^{145}$ But that term is not apt for de facto marriages. If a reference to marital behavior were to be used, the more apt term would be "idealmarriage-like." Formal marriages need not, and many would not, meet the standard for de facto marriages. In addition, some same-sex cohabitants rights advocates object to the "marriage-like" term. ${ }^{146}$ Most of the Commonwealth statutes avoid the term. Some use language such as "living together as a couple on a genuine domestic basis" or just "living together as a couple." 147 Others use language such as "a relationship of some permanence, if they are the natural or adoptive parents of a child." 148 Some of the statutes require the couple to have lived together for a certain period of time, such as three or more years. ${ }^{149}$ The ALI standard is that the couple must "for a

145 See British Columbia Family Law Act $\S 3(1)(\mathrm{b})$; Queensland Commonwealth Powers (De Facto Relationship) Act $2003 \S 3$.

${ }^{146}$ See, e.g., Mary Louise Fellows et al., Committed Partners and Inheritance: An Empirical Study, 16 LAW \& INEQ. J. 1, 27 (1998); Douglas NeJaime, Before Marriage: The Unexplored History of Nonmarital Recognition and Its Relationship to Marriage, 102 CAL. L. REV. 87, 114-125, 154-160 (2014); E. Gary Spitko, An Accrual/Multi-Factor Approach to Intestate Inheritance Rights for Committed Partners, 81 ORE. L. REV. 255, 327-28 (2002).

${ }^{147}$ See Family Law Act 1975 § 4AA(1) (Austl.); New South Wales Property (Relationships) Act $1984 \S 4(1)$; New Zealand Property (Relationship) Act 1976 $\S 2 \mathrm{D}(1)(\mathrm{b})$; Queensland Acts Interpretation Act $1954 \S 32 \mathrm{DA}(1)$; UK Cohabitation Rights Bill § 2(1)(a).

148 See Ontario Family Law Act $\S 29(\mathrm{~b})$; Alberta Adult Interdependent Relationships Act, SA 2002 § 3(1)(a)(ii).

149 See British Columbia Family Law Act $\$ 3(1)(b)$ ("for a continuous period of at least 2 years"); Queensland Succession Act $1981 \S 5 \mathrm{AA}(2)(\mathrm{b})(\mathrm{ii})$ ("for a continuous period of at least 2 years ending on the decedent's death"); Ontario Family Law Act $\S 29$ (a) ("continuously for a period of not less than three years"); UK Cohabitation Rights Bill $\S 2(2)(d)$ ("for a continuous period of three years or more"). 


\section{Prepublication Draft: Marital Rights for Unmarried Partners?}

significant period of time share a primary residence and a life together as a couple." 150

In determining whether the standard has been satisfied, most of the Commonwealth statutes and the ALI Unmarried Partner Statute then provide a list of factors to be taken into account. Two features of all of the statutory lists are that they are not restrictive, meaning that factors not on the list can be taken into account, and are not conjunctive, meaning that not all of the factors have to be present. Most of the statutes that do not require cohabitation for a certain period of time list the duration of the cohabitation as a factor to be considered. ${ }^{151}$ Most of the statutes list intermingling of finances and formalizing legal obligations and responsibilities as factors, for example, whether the couple had a joint checking or other types of accounts, owned property in joint tenancy, one named the other or both named each other as beneficiary of life insurance or pension benefit plans, and so on. ${ }^{152}$ Many of the statutes list having children as a factor. ${ }^{153}$ One of the statutes references a sexual relationship, ${ }^{154}$

${ }^{150}$ ALI UNMARRIED PARTNER STATUTE, supra note 138, § 6.03(1).

${ }^{151}$ See Family Law Act 1975 § 4AA(2)(a) (Austl.); New South Wales Property (Relationships) Act 1984 § 4(2)(a); Northern Territory De Facto Relationships Act $1991 \S 3 \mathrm{~A}(2)(\mathrm{a})$; Queensland Acts Interpretation Act 1954 § 32DA(2)(b); New Zealand Property (Relationships) Act 1976 § 2D(a); ALI UNMARRIED PARTNER STATUTE, supra note 138, at $\S 6.03(3)$.

${ }^{152}$ See Family Law Act 1975 § 4AA(2)(d) (Austl.); New South Wales Property (Relationships) Act $1984 \S 4(2)(d)$, (e); Northern Territory De Facto Relationships Act $1991 \S 3 \mathrm{~A}(2)(\mathrm{d})$, (e); Queensland Acts Interpretation Act 1954 §32DA(2)(d), (e); New Zealand Property (Relationships) Act $1976 \S 2 \mathrm{C}(2)(\mathrm{d})$, (e); ALI UNMARRIED PARTNER STATUTE, supra note 138, at $\S 6.03(7)(\mathrm{b})$.

${ }^{153}$ See Family Law Act $1975 \S 4$ AA(2)(h (Austl.)); New South Wales Property (Relationships) Act $1984 \S 4(2)(\mathrm{g})$; Northern Territory De Facto Relationships Act $1991 \S 3 \mathrm{~A}(2)(\mathrm{g})$; Queensland Acts Interpretation Act 1954 § 32DA(2)(g); New Zealand Property (Relationships) Act $1976 \S 2 \mathrm{C}(2)(\mathrm{g})$; ALI UNMARRIED PARTNER STATUTE, supra note 138, at $\S 6.03(7)(l)$. $C f$. British Columbia Family Law Act $\S$ $3(1)(b)(2)$ ("A person is a spouse ... if the person ... has a child with the other person.").

154 See Family Law Act $1975 \S 4 \mathrm{AA}(2)(\mathrm{c})$ (Austl.) ("whether a sexual relationship exists"). 
and others take account of the couple's "reputation and public aspects of the relationship."155 Again, all of the statutes are aiming at the same requirement: whether or not the couple's behavior demonstrates enough of a commitment to one another to declare that they have become married in fact. The statutes list a miscellany of other factors, such as the performance of household tasks, ${ }^{156}$ but the foregoing are the main ones. Intermingling finances, formalizing legal obligations, and having children together are important factors not only because they show that the couple had a strong commitment to one another but also because they are subject to objective evidence. ${ }^{157}$ These factors serve another function as well: They protect older widows and widowers who began cohabiting later in life, especially those who have adult children by prior marriages, from being caught up in a de facto marriage against their wishes. Older cohabiting couples will not have children together and are more likely to keep their finances separate. $^{158}$

${ }^{155}$ See Family Law Act 1975 § 4AA(2)(i) (Austl.); New South Wales Property (Relationships) Act 1984 § 4(2)(i); Northern Territory De Facto Relationships Act $1991 \S 3 \mathrm{~A}(2)(\mathrm{i})$; Queensland Acts Interpretation Act 1954 § 32DA(2)(i); New Zealand Property (Relationships) Act 1976 §D(2)(i); ALI UNMARRIED PARTNER STATUTE, supra note 138, at $\S 6.03(7)(\mathrm{i})$.

${ }^{156}$ See, e.g., Queensland Acts Interpretation Act 1954 32DA(2)(h).

157 " [C]ohabiting couples pool their funds and share expenses just as married couples do." D'Vera Cohn, Pew Research Center, Cohabiting Couples and Their Mo n e y, $\quad \mathrm{Nov} . \quad 22, \quad 2012, \quad$ a v a i $1 \mathrm{ab} l \mathrm{e} \quad \mathrm{at}$ http://www.pewsocialtrends.org/2011/11/22/cohabiting-couples-and-their-money/.

${ }^{158}$ See, e.g., Sheri Stritof, Tips for Cohabiting Seniors ("Do not combine your assets. Keep your bank accounts, brokerage accounts, etc., separate.”), available at http://marriage.about.com/cs/cohabitation/a/cohabseniors_2.htm. 
Prepublication Draft: Marital Rights for Unmarried Partners?

Drawing on these Commonwealth, ALI, and other sources, ${ }^{159}$ as well as on the case law noted in Part II.B.2, I would like to put forward for discussion a Draft De Facto Marriage Act:

\section{Draft De Facto Marriage Act}

Section 1. [De Facto Marriage; De Facto Spouses;

Consequences.] For purposes of all statutes in this state, two individuals are married to one another in fact if their relationship meets the requirements of this section. If so, their marriage is a de facto marriage and they are de facto spouses. A de facto marriage has the same status as a formal marriage. The parties to a de facto marriage are spouses. If one of them dies, the survivor is the decedent's surviving spouse.

Section 2. [De Facto Marriage; Requirements.] To be married de facto, the individuals must (i) be unmarried adults; (ii) not be prohibited from marrying each other under the law of this state by reason of a blood relationship; and (iii) must be or have been sharing a common household in a committed relationship.

Section 3. [Common Household.] For purposes of sections 2 and 5, "sharing a common household" or "shared a common household" means that the individuals shared the same place to live, whether or not one or both had other places to live and whether or not one or both were physically residing somewhere else at the time in question. The right to occupy the common household need not have been in both of their names.

Section 4. [Committed Relationship; Factors.] For purposes of section 2, a "committed relationship" is a

159 See, e.g., Mathew Fawcett, Taking the Middle Path: Recent Swedish Legislation Grants Minimal Property Rights to Unmarried Cohabitants, 24 FAM. L.Q. 179 (1990) (reporting on Swedish legislation); Stępień-Sporek \& Margaret Ryznar, supra note 133, (reporting on Polish legislation). The draft De Facto Marriage Act is adapted from an intestacy statute I proposed long ago in Waggoner, Marital Property Rights in Transition, supra note 77, 59 Mo. L. REV. at 79-80. Other scholars subsequently built upon that intestacy proposal. See T.P. Gallanis, Inheritance Rights for Domestic Partners, 79 TUL. L. REV. 54, 87-91 (2004); E. Gary Spitko, supra note 146 at 345-49. 
Prepublication Draft: Marital Rights for Unmarried Partners?

relationship in which two individuals have chosen to share one another's lives in a long-term and intimate relationship of mutual caring. Although no single factor or set of factors determines whether a relationship qualifies as committed, the following factors are among those to be considered:

(1) the purpose, duration, constancy, and degree of exclusivity of the relationship;

(2) the degree to which the individuals intermingled their finances, such as by maintaining joint checking, credit card, or other types of accounts, sharing loan obligations, sharing a mortgage or lease on the household in which they lived or on other property, or titling the household in which they lived in joint tenancy;

(3) the degree to which the individuals formalized legal obligations, intentions, and responsibilities to one another, such as one or both naming the other as primary beneficiary of life insurance or employee benefit plans, as agent to make health care decisions, or as a significant beneficiary of a will or trust;

(4) whether the couple shared in parenting a child and the degree of joint caring and support given the child; and

(5) the degree to which the individuals held themselves out to others as married or the degree to which the individuals held themselves out to others as emotionally and financially committed to one another on a permanent basis.

Section 5. [Presumption.] Two individuals are presumed to be or have been in a committed relationship if they shared a common household with their minor child for a continuous period totaling [four] or more years. A child is "their child" if the child is treated as their child under the law of this [state]. The presumption can only be rebutted by clear and convincing evidence. 


\section{Prepublication Draft: Marital Rights for Unmarried Partners?}

The Draft Act is a comprehensive de facto marriage act, not restricted to dissolution, succession, or any other purpose. Without an obvious limiting principle that would justify a narrower scope, the Draft Act proceeds on the basis that committed partners who are married in fact for one purpose are married in fact for all purposes. ${ }^{160}$

The Draft uses the term "committed relationship" instead of "marriage-like relationship." By necessity, however, the Draft Act uses the term "de facto marriage." There is a vast patchwork of state and federal statutes that grant benefits and impose obligations in cases of "marriage." As of 2004, federal law alone had 1138 statutory provisions that condition benefits, rights, and privileges on "marriage." 161 It would be a near-impossible task to persuade the federal and state legislatures to amend all of those statutes to say "marriage or committed relationship." Another possibility would be to propose a general statute providing that wherever a statute uses the term "marriage" or "spouses," the term includes committed relationships as defined in the statute. ${ }^{162}$ While enacting such a statute at the state level might be possible, persuading Congress to move on such a statute would be very difficult. For now, my conclusion is that if a couple in a committed relationship is to acquire the benefits of marriage under both state and federal law, the statute has to deem the couple to "married."

I noted earlier that the time may come when a couple's behavior accumulates enough to reach a tipping point - the time when a court

160 Accord,. Queensland Acts Interpretation Act 1954 § 32DA; UK Cohabitation Rights Bill.

${ }^{161}$ See Letter from General Accounting Office (GAO) to Senator Bill Frist (Jan. 23, 2004), available at http://www.gao.gov/new.items/d04353r.pdf. An earlier report found 1049 such statutory provisions. See Letter from GAO to Representative Henry Hyde (Jan. 31, 1997), available at http://www.gao.gov/archive/1997/og97016.pdf. Attached to both letters are lists of the statutory provisions by section numbers and topics.

162 Although that is the approach in Queensland (see Queensland Acts Interpretation Act 1954 § 32DA), enacting that approach would be far more difficult in the federal and state system of the United States. 
Prepublication Draft: Marital Rights for Unmarried Partners?

of competent jurisdiction could justifiably declare the couple's relationship as having reached committed status. The Draft Act, however, along with the Commonwealth statutes and the ALI Unmarried Partner Statute, does not, and probably should not, provide a mechanism for automatically declaring the couple as married in fact right then. Couples who deliberately decline to marry should not have their decision overridden. Consequently, the Draft Act is not set up to be self-executing. A court judgment is required. ${ }^{163}$ Even though a court judgment would probably be obtainable at the tipping point, a cohabiting couple in a harmonious committed relationship would not likely seek one. If such a couple decided that they want to qualify for all federal as well as state benefits and obligations of marriage, they would just get married.

The Draft Act, as it currently stands, is silent regarding whether a de facto marriage becomes effective on the date of the judgment or on an earlier date. ${ }^{164}$ Whether the Draft Act should expressly allow or prohibit a retroactive judgment or leave the question to the discretion of the court is debatable. A couple who had reached the tipping point before the date of the judgment might benefit from a judgment that they were married ex ante, so that, for example, previous gifts from one to the other qualified for the federal gift tax marital deduction ${ }^{165}$ or that previous filings of joint income tax returns ${ }^{166}$ were lawful. Failing to file a gift tax return or filing a false income tax return could expose the couple to civil or criminal penalties. ${ }^{167}$ Whether a

${ }^{163}$ In Commissioner v. Estate of Bosch, 387 U.S. 456, 465 (1967), the Supreme Court held that the Internal Revenue Service must honor judgments of a state's highest court, but it need only give "proper regard" to judgments of lower state courts.

${ }^{164}$ In comparison, the British Columbia Family Law Act $\S 3(3)$ provides: "A relationship ... begins on the date on which they began living together in a marriagelike relationship."

165 See I.R.C. $\$ 2523$.

166 See I.R.C. $\S \S 1(a), 6013$ to 6015 . The Internal Revenue Service does not require proof of marriage from couples filing joint income tax returns.

${ }^{167}$ See I.R.C. $\S \S 6672,6702,7203,7206$. 


\section{Prepublication Draft: Marital Rights for Unmarried Partners?}

retroactive de facto marriage judgment would be a defense is not clear. In a decades-old revenue ruling regarding common-law marriages, which, so far as it goes, should be equally applicable to de facto marriages, the Internal Revenue Service was frustratingly imprecise regarding whether a judgment is even required. ${ }^{168}$ Surely, in the case of a de facto marriage claim, the Service would not take the couple's word for it or make its own independent determination regarding such a matter on a case-by-case basis. Here is what the Service said about common-law marriages:

The marital status of individuals as determined under state law is recognized in the administration of the Federal income tax laws. Therefore, if applicable state law recognizes common-law marriages, the status of individuals living in such relationship that the state would treat them as husband and wife is, for Federal income tax purposes, that of husband and wife.

The foregoing position of the Internal Revenue Service with respect to a common-law marriage is equally applicable in the case of taxpayers who enter into a common-law marriage in a state which recognizes such relationship and who later move into a state in which a ceremony is require to initiate the marital relationship.... Also, for the purpose of filing a joint income tax return under section 6013(a) of the Code, a common-law wife in a state which

168 Rev. Rul. 58-66, 1958-1 C.B. 60. The ruling is unusual, because the analysis was not based on a statement of facts. A statement of facts would presumably have indicated whether the couple had obtained a common-law marriage judgment. In a later ruling recognizing same-sex marriages for federal tax purposes (Rev. Rul. 2013-17, I.R.B. 2013-38), the Service reaffirmed the 1958 ruling on common-law marriages. The 2013 ruling, however, was as imprecise as the 1958 ruling regarding whether a common-law marriage judgment is required. The Service offered only the conclusory description of couples who had "entered into" or "established" common-law marriages. Anecdotally, a couple of messages on file with the author posted on the ACTEC list serve dated 10-21-15 from practitioners in a common-law marriage state (Texas) indicate that the IRS did not question a federal estate-tax marital deduction claimed on the decedent's estate tax return when the return was accompanied by a statement explaining the facts supporting their marriage at common law. 


\section{Prepublication Draft: Marital Rights for Unmarried Partners?}

recognizes such marriages will be considered to be the taxpayer's spouse.

Just as a high percentage of formal marriages eventually unravel, ${ }^{169}$ a similar or higher percentage of committed relationships will also eventually unravel. A couple who amicably break up after cohabiting in a relationship that could be deemed by a court to be a de facto marriage would not have a divorce remedy imposed on them. They would be free to disentangle their relationship without interference from a court under a de facto marriage act. But if one partner deprives the other of marital rights to which the other feels entitled, a de facto marriage act would provide a remedy. If they break up, the plaintiff would be able to seek alimony ${ }^{170}$ and a property settlement ${ }^{171}$ under the divorce laws. ${ }^{172}$ If one of them dies, the plaintiff would be able to seek an intestate or forced share under state law and an estate tax marital deduction ${ }^{173}$ under federal law. The plaintiff would have the burden of persuasion in these cases, except that the presumption in section 5 of the Draft Act would reverse that burden regarding the existence of a committed relationship. To benefit from the presumption, the plaintiff would first have to prove

${ }^{169}$ See MARRIAGE IN AMERICA, supra note 10, at 67 ("The American divorce rate today is about twice that of 1960, but has declined since hitting its highest point in our history in the early 1980s. For the average couple marrying for the first time in recent years, the lifetime probability of divorce or separation now falls between 40 and 50 percent.").

${ }^{170}$ For federal income tax purposes, alimony is ordinary income taxable to the recipient (I.R.C. $\S 61(8)$ ) and deductible by the payor (I.R.C. $\S 215$ ).

${ }^{171}$ For federal income tax purposes, no gain or loss is recognized on a transfer of property incident to a divorce, but the transferee takes the transferor's adjusted basis. See I.R.C. $\S 1041$.

172 In refining the Draft Act, consideration should be given to possible differences in divorce laws and to the handling and possible recharacterization of separate property as marital property between equitable distribution states and community property states. See, e.g., ALI UNMARRIED PARTNER STATUTE, supra note 138 , at $\S 6.04(3) \& \mathrm{cmt} . b$.

${ }^{173}$ See I.R.C. $\S 2056$. 
Prepublication Draft: Marital Rights for Unmarried Partners?

the set of facts that the statute requires as a precondition: that the couple continuously shared a common household with their minor child for the requisite number of years. Living together with their child in a common household for a continuous period is a strong indication that the couple has crossed the line into de facto marriage. ${ }^{174}$ The Draft Act defines "their child" as a child who is treated as their child by applicable state law. That could be a genetic or adopted child or a child resulting from assisted reproduction or a surrogacy arrangement. ${ }^{175}$ There could be and often would be more than one such child, of course, ${ }^{176}$ but one is all the statute requires to trigger the presumption.

A divorced de facto spouse and a surviving de facto spouse could also apply for Social Security benefits. A divorced spouse who is unmarried and age 62 or older is entitled to benefits, but only if the marriage lasted ten years or longer, ${ }^{177}$ raising in another context the question of a retroactive de facto marriage judgment. A surviving spouse is entitled to retirement benefits as early as age 60 if the deceased spouse worked long enough under Social Security to have

${ }^{174}$ In MERLE H. WeInER, A PARENT-PARTNER STATUS FOR AMERICAN FAMILY LAW 135 (2015), the author proposes that state law recognize a new "parentpartner" status for married and unmarried couples that automatically begins upon birth of a common child and terminates when the child reaches the age of majority. The "parent-partner" status would legally obligate each parent, whether or not sharing a common household with the other parent: (1) "to render reasonable assistance if the other parent's life is endangered;" (2) "not to physically or psychologically abuse the other parent;" (3) "to engage in 'relationship work' at the transition to parenthood and at the demise of the romantic relationship;" (4) "to act honestly and fairly when contracting with each other about an aspect of their family relationship;" and (5) "to 'give or share,' so that neither parent would perform an unfairly disproportionate amount of caregiving for the couple's child."

175 See, e.g., UNIF. PROBATE CODE $\S \S 2-115$ to -122 .

${ }^{176}$ See supra notes 24-27 and accompanying text.

177 See Social SeCURITY Administration, Retirement Planner: If You Are Divorced, available at http://www.ssa.gov/planners/retire/divspouse.html. 


\section{Prepublication Draft: Marital Rights for Unmarried Partners?}

received retirement benefits. ${ }^{178}$ For near or below poverty-line couples, ${ }^{179}$ Social Security benefits might be the main asset worth fighting for.

There is no danger that de facto marriages would replace or discourage formal marriages, any more than recognition of commonlaw marriages has discouraged formal marriage. ${ }^{180}$ In the case of formal marriage, the marriage certificate automatically grants full marital rights to the married partners. Legislation granting that same status to unmarried partners would still require case-by-case adjudication to determine whether the criteria have been satisfied.

\section{CONCLUSION}

If the marriage and cohabitation trends continue - downward for marriage, upward for cohabitation — or even if the trends stabilize at the current rates or reverse somewhat due to same-sex marriages or a dramatically improved economy sometime in the future, the lack of marital rights for committed partners will persist as a problem until a solution is found. Pressure will grow for a legislative blueprint for gaining those rights, especially as more and more aggrieved partners seek a remedy when they break up or when one dies without benefitting the survivor. Commonwealth countries have already moved on the subject ${ }^{181}$ and Parliament in the United Kingdom has it under active consideration. ${ }^{182}$ In this country, the ALI has put its prestige behind a remedy for the breaking-up cases ${ }^{183}$ and scholars are now taking notice of the problem. ${ }^{184}$ A Uniform De Facto Marriage

\footnotetext{
${ }^{178}$ See SOCIAL SECURITY ADMINISTRATION, Survivors Planner: If You Are the Worker's Widow or Widower, available a t http://www.socialsecurity.gov/planners/survivors/ifyou2.html.

179 See supra note 68-70 and accompanying text.

${ }^{180}$ See supra text accompanying notes 111-113 and supra Table 3.

${ }^{181}$ See supra notes 134-136.

${ }^{182}$ See supra note 137.

183 See supra note 138.

${ }^{184}$ See supra note 133.
} 
Prepublication Draft: Marital Rights for Unmarried Partners?

Act that grants de facto marriages the same status as formal marriages would entitle de facto spouses to all marital rights under federal as well as state laws. ${ }^{185}$

${ }^{185}$ See supra text accompanying notes 39-49. 